\title{
CUADRO DE UNIFICACIONES DE JURISPRUDENCIA DICTADAS POR LA EXCMA. CORTE SUPREMA (JULIO DE 2014 A JULIO DE 2015)
}

\author{
Hugo Fábrega Vega* \\ Cristián Olavarría Rodríguez ${ }^{* *}$ \\ Abogados \\ Centro Chileno de Estudios de Derecho del Trabajo A.G. (CEDET)
}

\section{PRELIMINARES}

El presente trabajo tiene por objeto poner a disposición del público un cuadro de las sentencias en Unificación de Jurisprudencia dictadas por la Cuarta Sala de la Excma. Corte Suprema, con una pequeña glosa descriptiva y su vinculación con otras materias objeto de la competencia que detenta aquella sala especializada en materia laboral y de seguridad social del más alto tribunal del país.

Para cumplir tales efectos y complementar el trabajo efectuado a través del informe $\mathrm{N}^{\circ} 33$ 2014 elaborado por la Dirección de Estudios, Análisis y Evaluación de la Corte Suprema, se advierte que el estudio toma en consideración el período posterior a este, o sea, desde Julio de 2014 a Julio de 2015.

Por último, se hace presente que los autores han seleccionado algunos criterios de importancia práctica que han sido rechazados en Unificación de Jurisprudencia, advirtiendo, asimismo, que han quedado fuera de este análisis los criterios relacionados con Estatuto Docente y bono S.A.E.

Contacto: hfabrega@ahmt.cl

. Contacto: cristian.olavarria@ppulegal.com 
Hugo Fábrega Vega, Cristián Olavarría Rodríguez / Cuadro de unificaciones de jurisprudencia dictadas por la Excma. Corte Suprema (julio de 20I4 a julio de 2015)

\section{UNIFICACIONES}

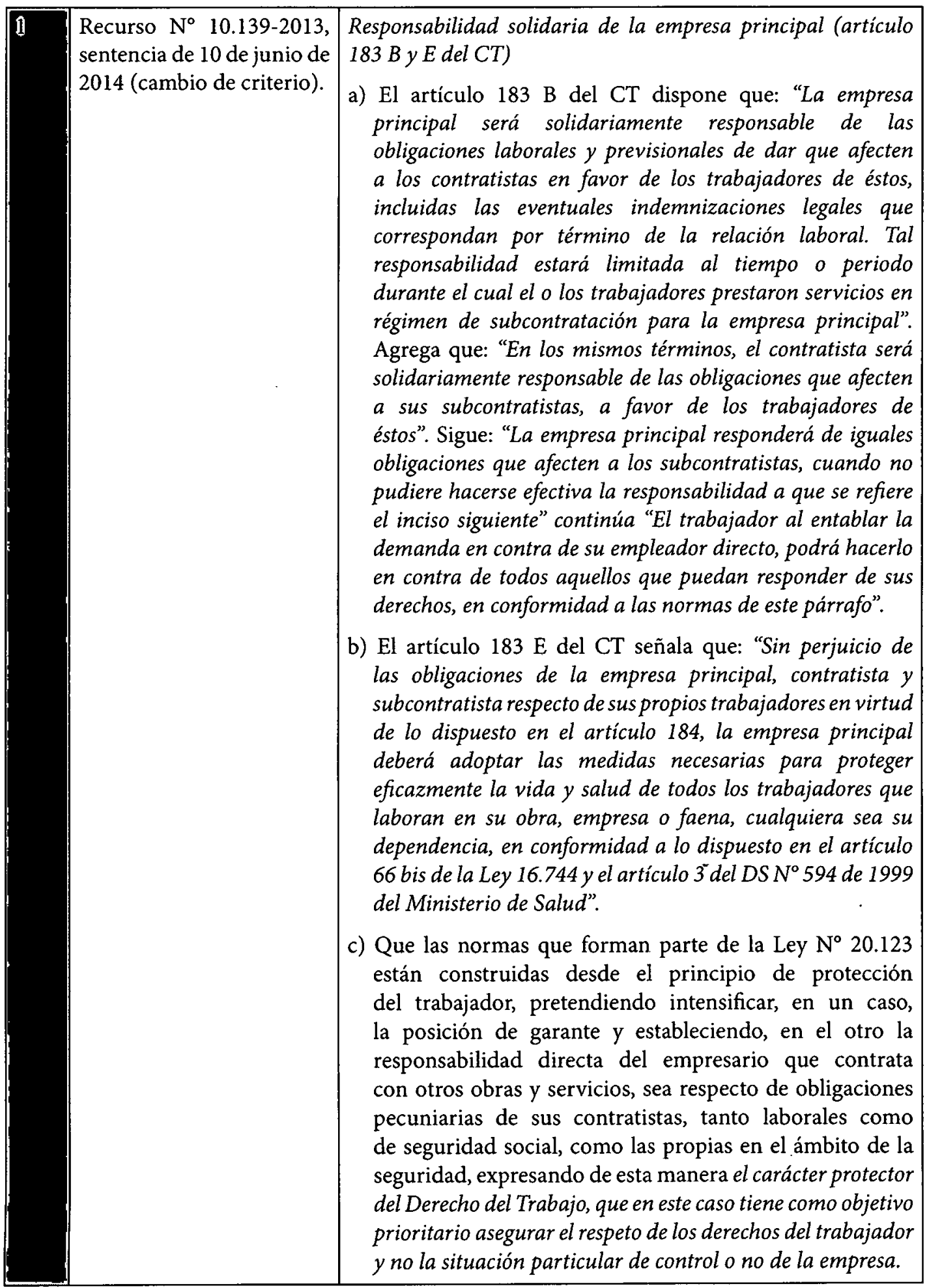




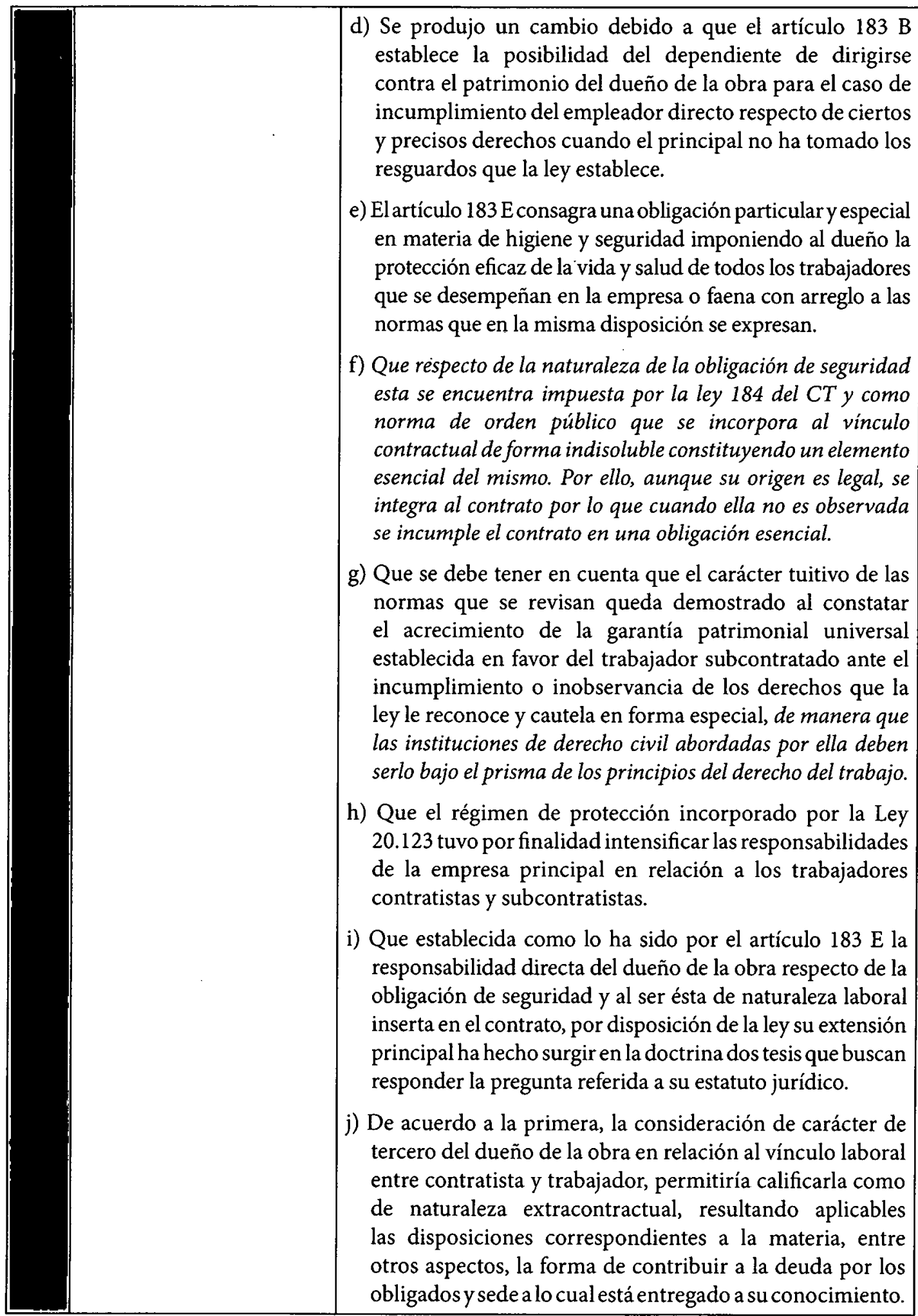


Hugo Fábrega Vega, Cristián Olavarría Rodríguez / Cuadro de unificaciones de jurisprudencia dictadas por la Excma. Corte Suprema (julio de 2014 a julio de 2015)

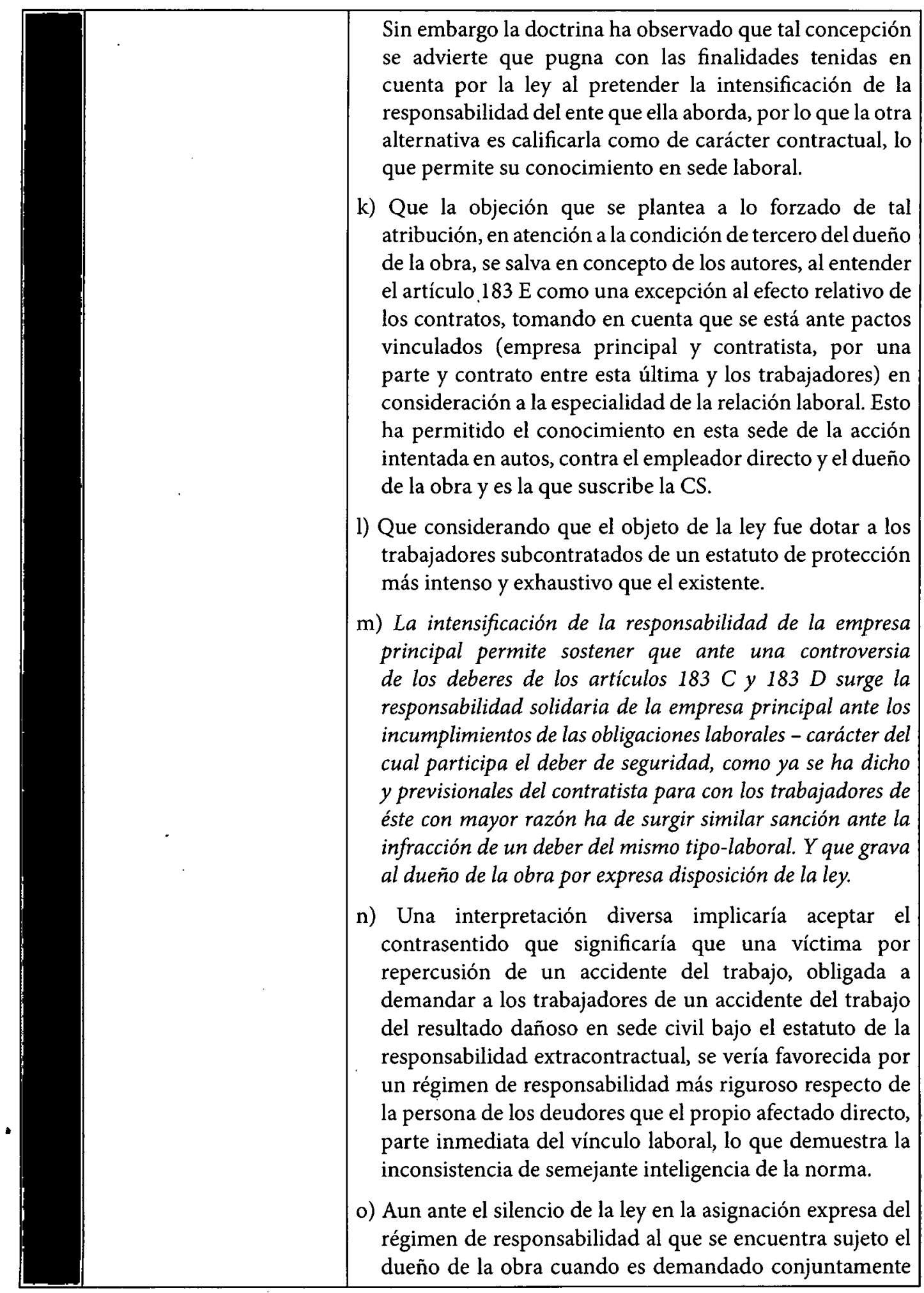




\begin{tabular}{|c|c|c|}
\hline & & $\begin{array}{l}\text { con el contratista, cada uno en virtud de la infracción } \\
\text { de sus respectivos deberes que hicieron posible un } \\
\text { único resultado lesivo, la comprensión conjunta de las } \\
\text { disposiciones mencionadas bajo el prima interpretativo } \\
\text { propio del Derecho Laboral que permite a los jueces la } \\
\text { asignación en sentido de sus disposiciones conforme al } \\
\text { criterio pro operario que posibilita la integración de las } \\
\text { normas que regulan una misma materia, fuerza a concluir } \\
\text { que tal estatuto es el propio de la solidaridad, con los } \\
\text { matices que el derecho laboral introduce en su comprensión, } \\
\text { conforme se advierte de los términos de la propia Ley } \\
20.123 \text {. } \\
\text { p) En razón de lo concluido no puede conculcarse con lo } \\
\text { resuelto en los artículos } 1511 \text { y } 1526 \text { del CC, por cuanto } \\
\text { la interpretación que se ha dado a las normas en análisis } \\
\text { es la que permite su máxima expresión, coherente con los } \\
\text { fines tenidos en consideración. } \\
\text { q) Luego la responsabilidad es solidaria. } \\
\text { r) El pago de la indemnización por daño moral convierte al } \\
\text { deber de cuidado infraccionado en una obligación de dar. }\end{array}$ \\
\hline 2 & $\begin{array}{l}\text { Recurso } N^{\circ} 16.896-2013 \text {, } \\
\text { sentencia de } 17 \text { de junio } \\
\text { de } 2014 \text {. }\end{array}$ & $\begin{array}{l}\text { Desafuero y expresión "podrá" (artículo } 174 \text { del CT) } \\
\text { Se reiteran argumentos de fallos anteriores. }\end{array}$ \\
\hline 3 & $\begin{array}{l}\text { Recurso } \mathrm{N}^{\circ} 12.514-2013 \text {, } \\
\text { sentencia de } 23 \text { de junio } \\
\text { de } 2014 \text {. }\end{array}$ & $\begin{array}{l}\text { Perdón de la causal. Improcedencia en el despido indirecto } \\
\text { a) Que el inciso } 2^{\circ} \text { del artículo } 5 \text { del CT establece que } \\
\text { los derechos laborales son irrenunciables. Implica la } \\
\text { posibilidad jurídica de privarse voluntariamente de una } \\
\text { o más ventajas concedidas por el derecho laboral en } \\
\text { beneficio propio. } \\
\text { b) El perdón de la causal es una institución elaborada por } \\
\text { la doctrina laboral a partir de dos ideas o nociones, a } \\
\text { saber, la de reconocimiento de la voluntad presunta y la } \\
\text { de consolidación de las situaciones, pues si el empleador } \\
\text { nada hace para sancionar la falta o inconducta del } \\
\text { trabajador dentro de un periodo más o menos inmediato } \\
\text { a su comisión, se presume su voluntad de perdonarla. } \\
\text { Lo que también ocurre si aplicó una sanción de menor } \\
\text { entidad, caso en el que se entremezclaría con el principio } \\
\text { de non bis in ídem. } \\
\text { c) No puede aceptarse la figura del perdón de la causal cuando } \\
\text { es el empleador el que incumple gravemente las obligaciones } \\
\text { que le impone el contrato y el dependiente deja transcurrir }\end{array}$ \\
\hline
\end{tabular}


Hugo Fábrega Vega, Cristián Olavarría Rodríguez / Cuadro de unificaciones de jurisprudencia dictadas por la Exema. Corte Suprema (julio de 2014 a julio de 2015)

\begin{tabular}{|c|c|c|}
\hline & & $\begin{array}{l}\text { un tiempo prolongado antes de accionar por auto despido } \\
\text { o despido indirecto, razón por la que se debe concluir que } \\
\text { al admitirse la alegación formulada por el demandado, en } \\
\text { orden a la demanda subsidiaria por despido indirecto debe } \\
\text { ser desestimada por haber operado el perdón de la causal } \\
\text { se conculcó lo que dispone el inciso } 2 \text { del artículo } 5 \text { del CT. } \\
\text { d) Considerando que el despido indirecto provoca el efecto que } \\
\text { el trabajador queda cesante, lo que trae consigo un estado de } \\
\text { incertidumbre económica, se puede elaborar como máxima } \\
\text { de experiencia una que señale que el trabajador vacilará, se } \\
\text { tomará tiempo antes de poner término al contrato y que por } \\
\text { lo mismo, no puede ser fruto de una decisión apresurada o } \\
\text { precipitada. }\end{array}$ \\
\hline 4 & $\begin{array}{l}\text { Recurso } N^{\circ} 14656-2013 \text {, } \\
\text { sentencia de } 8 \text { de julio de } \\
2014 \text {. }\end{array}$ & $\begin{array}{l}\text { Finiquito (articulo } 177 \text { del CT) } \\
\text { a) El finiquito legalmente celebrado constituye un equivalente } \\
\text { jurisdiccional que tiene la misma fuerza que una sentencia } \\
\text { firme o ejecutoriada y da cuenta del término de la relación } \\
\text { en las condiciones que en él se consignan. } \\
\text { b) El poder liberatorio se restringe a todo aquello en que las } \\
\text { partes han concordado expresamente y no se extiende a los } \\
\text { aspectos en que el consentimiento no se formó, sea porque } \\
\text { una de las partes formula la reserva correspondiente, sea } \\
\text { porque se trate de derechos uobligaciones no especificados } \\
\text { por los comparecientes, sea por cualesquiera otras razones } \\
\text { que el entendimiento humano pudiera abarcar. } \\
\text { c) En el instrumento que se examina nada se consignó } \\
\text { especificamente en relación con el accidente de trabajo que } \\
\text { padeció el actor y que era conocido de la demandada, de } \\
\text { modo que la amplitud de la declaración no puede abarcar } \\
\text { la acción que se ventila en esos autos, pues por tratarse de } \\
\text { una transacción-en la especie, contrato por el que las partes } \\
\text { precaven un eventual litigio, de acuerdo con lo dispuesto } \\
\text { en el artículo 2446 del Código Civil- en la que se ajustan } \\
\text { cuentas pendientes, es dable exigirle la especificidad } \\
\text { necesaria, en atención no sólo a los bienes jurídicos en } \\
\text { juego, esto es, derechos laborales de orden público, sino } \\
\text { también porque se trata de evitar o eludir un pleito, una } \\
\text { controversia, entre quienes comparecen a dicho ajuste } \\
\text { de cuentas, de modo que es dable requerir la máxima } \\
\text { nitidez en cuanto a las materias, derechos, obligaciones, } \\
\text { prestaciones, indemnizaciones, etc., sobre las cuales se ha } \\
\text { formado el consentimiento, con el objeto precisamente } \\
\text { de impedir las discusiones como la presente en que una }\end{array}$ \\
\hline
\end{tabular}




\begin{tabular}{|c|c|c|}
\hline & & $\begin{array}{l}\text { parte entiende que no ha transado y la otra, supone el } \\
\text { acuerdo y la renuncia de acciones. }\end{array}$ \\
\hline 5 & $\begin{array}{l}\text { Recurso } \mathrm{N}^{\circ} 1618-2014 \text {, } \\
\text { sentencia de } 30 \text { de julio de } \\
2014 \text { (rechaza recurso y } \\
\text { cambio de criterio). }\end{array}$ & 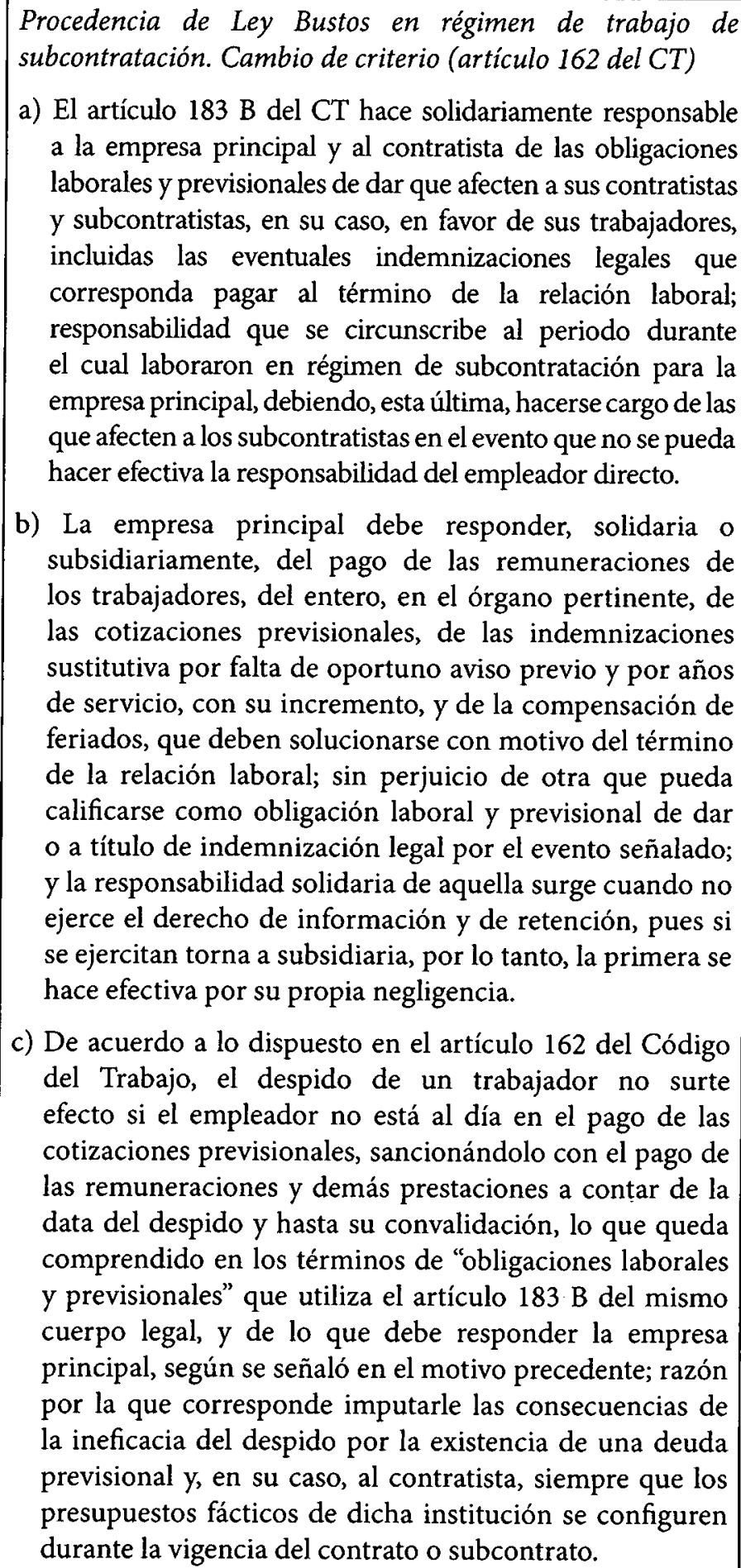 \\
\hline
\end{tabular}


Hugo Fábrega Vega, Cristián Olavarría Rodríguez / Cuadro de unificaciones de jurisprudencia dictadas por la Excma. Corte Suprema (julio de 2014 a julio de 2015)

\begin{tabular}{|c|c|c|}
\hline & . & $\begin{array}{l}\text { d) Que, no obsta a la conclusión anterior, la circunstancia que } \\
\text { la responsabilidad solidaria de la empresa principal esté } \\
\text { limitada al tiempo o periodo durante el cual los trabajadores } \\
\text { prestaron servicios en régimen de subcontratación, porque } \\
\text { como el hecho que genera la sanción que establece el articulo } \\
162 \text { del Código del Trabajo se presenta durante la vigencia } \\
\text { de dicho régimen, se debe concluir que la causa que provoca } \\
\text { su aplicación -no pago de las cotizaciones previsionales- se } \\
\text { originó en el ámbito que debe controlar y en el que la ley } \\
\text { le asignó responsabilidad, debido a la utilidad que obtiene } \\
\text { del trabajo prestado por los dependientes de un tercero y } \\
\text { por la necesidad de cautelar el fiel cumplimiento de las } \\
\text { obligaciones laborales y previsionales. } \\
\text { e) Que la referida conclusión está acorde con los objetivos de } \\
\text { la ley que regula el trabajo en régimen de subcontratación, } \\
\text { en la medida que establece un sistema de protección a los } \\
\text { trabajadores que se desempeñan en dichas condiciones, } \\
\text { ya que, como se indicó, instituyó respecto de la empresa } \\
\text { principal una responsabilidad solidaria y subsidiaria en lo } \\
\text { concerniente a las obligaciones laborales y previsionales } \\
\text { que debe asumir el contratista respecto de su dependiente, } \\
\text { para, en definitiva, estimular y velar por el cumplimiento } \\
\text { efectivo y oportuno de dichas obligaciones. } \\
\text { f) La nueva normativa que regula el trabajo en régimen de } \\
\text { subcontratación no excluye a la empresa principal de } \\
\text { la aplicación de la ineficacia del despido de que trata el } \\
\text { artículo } 162 \text { del Código del Trabajo, y tampoco fue materia } \\
\text { de discusión o indicación durante la tramitación de la ley } \\
\text { que la contiene, } \mathrm{N}^{\circ} 20.123 \text {, lo que se puede apreciar del } \\
\text { examen de la discusión parlamentaria llevada a cabo. }\end{array}$ \\
\hline 6 & $\begin{array}{l}\text { Recurso } N^{\circ} 545-2014 \text {, sen- } \\
\text { tencia de } 7 \text { de agosto de } \\
2014 \text {. }\end{array}$ & $\begin{array}{l}\text { Jornada mayor de } 30 \text { horas y hasta } 45 \text { es jornada completa. } \\
\text { Improcedencia de ingreso minimo proporcional } \\
\text { a) Se reiteran los mismos argumentos anteriores en el sentido } \\
\text { que las jornadas de trabajo inferiores a } 45 \text { horas semanales } \\
\text { pero superiores a } 30 \text { horas semanales, constituyen jornada } \\
\text { ordinaria de trabajo, toda vez que las partes han podido } \\
\text { libremente pactarla con una duración menor al máximo } \\
\text { legal y que no ha quedado encasillada dentro de lo que la } \\
\text { ley califica como jornada a tiempo parcial por exceder de } \\
\text { los parámetros legales. }\end{array}$ \\
\hline
\end{tabular}




\begin{tabular}{|c|c|c|}
\hline 7 & $\begin{array}{l}\text { Recurso } N^{\circ} 15.323-2013 \text {, } \\
\text { sentencia de } 7 \text { de agosto } \\
\text { de } 2014 \text {. }\end{array}$ & $\begin{array}{l}\text { Incumplimiento de pago de cotizaciones previsionales (articulc } \\
160 N^{\circ} 7 \text {-art } 171 \text { del CT) } \\
\text { a) El artículo } 58 \text { del CT dispone que el empleador deber } \\
\text { deducir de las remuneraciones los impuestos que la } \\
\text { graven, las cotizaciones de seguridad social. } \\
\text { b) Que tal descuento para los efectos de la seguridad socia } \\
\text { es obligatorio según lo estipula el artículo } 17 \text { del DL } 3500 \\
\text { c) Que la cotización es un gravamen que pesa sobre las } \\
\text { remuneraciones de los trabajadores el cual es descontado } \\
\text { por el empleador con la finalidad de ser enterado ante } \\
\text { el órgano previsional al que se encuentren afiliados sus } \\
\text { dependientes, junto al aporte que le corresponde a é } \\
\text { mismo sufragar dentro del plazo que fija la ley. } \\
\text { d) Que no enterar la cotización ante la institución previsional } \\
\text { reviste un incumplimiento de la obligación que impone } \\
\text { el contrato de trabajo consistente en el pago íntegro y } \\
\text { oportuno de la remuneración del trabajador. } \\
\text { e) Que el hecho que el articulo } 19 \text { del DL } 3500 \text { permita a } \\
\text { la parte empresarial una vez deducidas las cotizaciones } \\
\text { de las remuneraciones de los trabajadores no pagarlas } \\
\text { oportunamente al organismo previsional sino declararlas, } \\
\text { no deja de configurar un incumplimiento a las obligaciones } \\
\text { que impone el contrato de trabajo, sino que representa una } \\
\text { forma de facilitar su cobro, por una parte y a cambio de } \\
\text { disminuir la carga accesoria de carácter pecuniario que tal } \\
\text { atraso conlleva. } \\
\text { f) Que el declarar y no pagar las cotizaciones incurre en } \\
\text { incumplimiento grave de las obligaciones y permite el } \\
\text { ejercer la acción de despido indirecto. }\end{array}$ \\
\hline 8 & $\begin{array}{l}\text { Recurso } \mathrm{N}^{\circ} 3093-2014, \\
\text { sentencia de } 14 \text { de agosto } \\
\text { de } 2014 \text { (rechaza recurso) } \\
\text { (nuevo criterio). }\end{array}$ & $\begin{array}{l}\text { Incorporación de asignación de colación, movilización y } \\
\text { pérdida de caja } \\
\text { a) Las asignaciones de colación y movilización percibidas } \\
\text { regularmente por el trabajador atendido, principalmente, } \\
\text { que entiende se trata de una norma especial que pone } \\
\text { su atención en las cantidades que el trabajador hubiere } \\
\text { estado percibiendo con regularidad a la fecha de término } \\
\text { de la relación laboral, con independencia de que éstas } \\
\text { pudieren tener o no la calidad de remuneración según } \\
\text { lo preceptuado en el artículo } 41 \text { del mismo cuerpo legal } \\
\text { desde que por aplicación del principio de especialidad } \\
\text { consagrado en el artículo } 13 \text { del CC, el artículo } 172 \text { del } \\
\text { CT prima sobre el citado artículo } 41 \text { del CT. }\end{array}$ \\
\hline
\end{tabular}


Hugo Fábrega Vega, Cristián Olavarría Rodríguez / Cuadro de unificaciones de jurisprudencia dictadas por la Excma. Corte Suprema (julio de 2014 a julio de 2015)

\begin{tabular}{|c|c|c|}
\hline & & $\begin{array}{l}\text { b) En lo que respecto a la asignación de pérdida de caja le } \\
\text { es aplicable el argumento de la colación y movilización } \\
\text { debido a quetampoco tiene la naturaleza de remuneración. }\end{array}$ \\
\hline 9 & $\begin{array}{l}\text { Recurso } \mathrm{N}^{\circ} 3182-2014, \\
\text { sentencia de } 28 \text { de agosto } \\
\text { de } 2014 .\end{array}$ & $\begin{array}{l}\text { Jornada superior a } 30 \text { horas semanales e inferior a } 45 \text { horas } \\
\text { semanales. Improcedencia de pago proporcional de ingreso } \\
\text { minimo } \\
\text { Se reiteran los mismos argumentos que en fallos anteriores. }\end{array}$ \\
\hline 10 & $\begin{array}{l}\text { Recurso } N^{\circ} 3196-2014, \\
\text { sentencia de } 16 \text { de sep- } \\
\text { tiembre de } 2014 \text { (rechaza } \\
\text { recurso). }\end{array}$ & $\begin{array}{l}\text { Contrato por obra o faena. Contrato de concesión de servicio } \\
\text { de aseo en Coronel (artículo } 159 \mathrm{~N}^{\circ} 5 \text { ) } \\
\text { a) La causal del artículo } 159 \mathrm{~N}^{\circ} \text { del } \mathrm{CT} \text {, esto es, conclusión } \\
\text { del trabajo o servicio que dio origen al contrato, supone, } \\
\text { implícitamente, una temporalidad en la prestación de } \\
\text { tales servicios. De acuerdo al principio de estabilidad en } \\
\text { el empleo que recoge supone una ausencia de continuidad } \\
\text { en la labor que desarrolla el trabajador. } \\
\text { b) Que el título V del Libro I del CT que se denomina "De } \\
\text { la terminación del contrato de trabajo y estabilidad en } \\
\text { el empleo", de lo que se desprende que la estabilidad en } \\
\text { el empleo es consustancial en contratos de duración } \\
\text { indefinida. } \\
\text { c) La estabilidad supone que el trabajador tiene el derecho a } \\
\text { permanecer indefinidamente en el empleo hasta tanto no } \\
\text { se configure una justa causal de terminación de contrato } \\
\text { y si prospera el despido injustificado tiene el derecho a las } \\
\text { correspondientes indemnizaciones. } \\
\text { d) Este régimen no desconoce algunas causales objetivas de } \\
\text { terminación de contrato como el vencimiento del plazo } \\
\text { o la conclusión del trabajo o servicio que dio origen al } \\
\text { contrato a cuyo advenimiento expira el vínculo contractual } \\
\text { sin derechos a indemnizaciones legales para el trabajador. } \\
\text { e) El legislador para proteger la estabilidad en el empleo } \\
\text { consagra situaciones específicas que denotan un repudio } \\
\text { a la transgresión de tal principio, como por ejemplo las } \\
\text { presunciones de transformación de contratos de plazo, } \\
\text { incluso discontinuos en contratos de duración indefinida. } \\
\text { f) Que en relación con los contratos por obra o servicio no se } \\
\text { contempla como enlos contratos a plazo normas que regulen } \\
\text { su transformación en contratos de duración indefinida. } \\
\text { Ello no obsta para que el intérprete señale ciertos limites } \\
\text { temporales de los contratos por obra o servicio determinado. }\end{array}$ \\
\hline
\end{tabular}




\begin{tabular}{|c|c|c|}
\hline & $\cdot$ & $\begin{array}{l}\text { g) El principio de la continuidad tiene preferencia por los } \\
\text { contratos de duración indefinida. } \\
\text { h) Las actividades que dan origen a la causal prevista en el } \\
\mathrm{N}^{\circ} 5 \text { del artículo } 159 \text { del CT deben ser necesariamente } \\
\text { transitorias o de limitada duración conclusión que se } \\
\text { aviene a la estabilidad en el empleo. } \\
\text { i) En los contratos por obra o servicio existe un plazo, solo que } \\
\text { no es predeterminado, sino que se trata de un plazo tácito a } \\
\text { que se refiere el artículo } 1494 \text { del CC, no es concebible que se } \\
\text { pretenda utilizar el estatuto laboral de las obras temporales } \\
\text { para aplicarla a la prestación de servicios permanentes. }\end{array}$ \\
\hline 11 & $\begin{array}{l}\text { Recurso } N^{\circ} 674-2014 \text {, sen- } \\
\text { tencia } 11 \text { de septiembre de } \\
2014 \text {. }\end{array}$ & $\begin{array}{l}\text { Exclusión de limite de } 90 \text { UF para personas contratadas antes } \\
\text { del } 14 \text { de agosto de } 1981 \\
\text { a) El trabajador fue despedido en virtud del artículo } 161 \\
\text { inciso } 2 \text { del CT. } \\
\text { b) Le corresponde indemnización que contempla el } \\
\text { artículo } 163 \text { del CT que equivale a } 30 \text { días de la última } \\
\text { remuneración mensual por cada año de servicio y } \\
\text { fracción superior a seis meses prestados continuamente al } \\
\text { mismo patrón acotando que "Esta indemnización tendrá } \\
\text { un límite máximo de } 330 \text { días de remuneración", tope que } \\
\text { vino dado por el artículo } 5 \text { inciso } 2 \text { de la Ley No } 19.010 \\
\text { de } 23 \text { de noviembre de } 1990 \text { y que fue expresamente } \\
\text { excepcionado para los trabajadores ingresados antes del } \\
14 \text { de agosto de } 1981 \text {. } \\
\text { c) Elartículo } 7 \text { transitorio delCT dispone que los trabajadores } \\
\text { con contrato de trabajo vigente al } 1 \text { de diciembre de } 1990 \\
\text { y contratados con anterioridad al } 14 \text { de agosto de } 1981 \\
\text { tienen derecho a las indemnizaciones que les corresponde } \\
\text { sin el límite máximo a que se refiere el artículo } 163 \text {. } \\
\text { d) El ordenamiento es claro y definido en punto a que al } \\
\text { dependiente destacado por su antigüedad para con el } \\
\text { mismo empleador no se le merma la indemnización a los } \\
\text { mentados } 330 \text { días. } \\
\text { e) La interrogante: ¿El artículo } 7 \text { transitorio no se refiere } \\
\text { al máximo de } 90 \text { UF, debe inferirse que no se lo excluyó } \\
\text { respecto de quienes incorporados antes del } 14 \text { de agosto } \\
\text { de } 1981 \text { ? } \\
\text { f) Como al gerente fue desahuciado por el artículo } 161 \text { le } \\
\text { resulta aplicable el artículo } 170 \text { que a su turno le reconoce } \\
\text { la prerrogativa del } 163 \text { inciso } 2^{\circ} \text {. }\end{array}$ \\
\hline
\end{tabular}




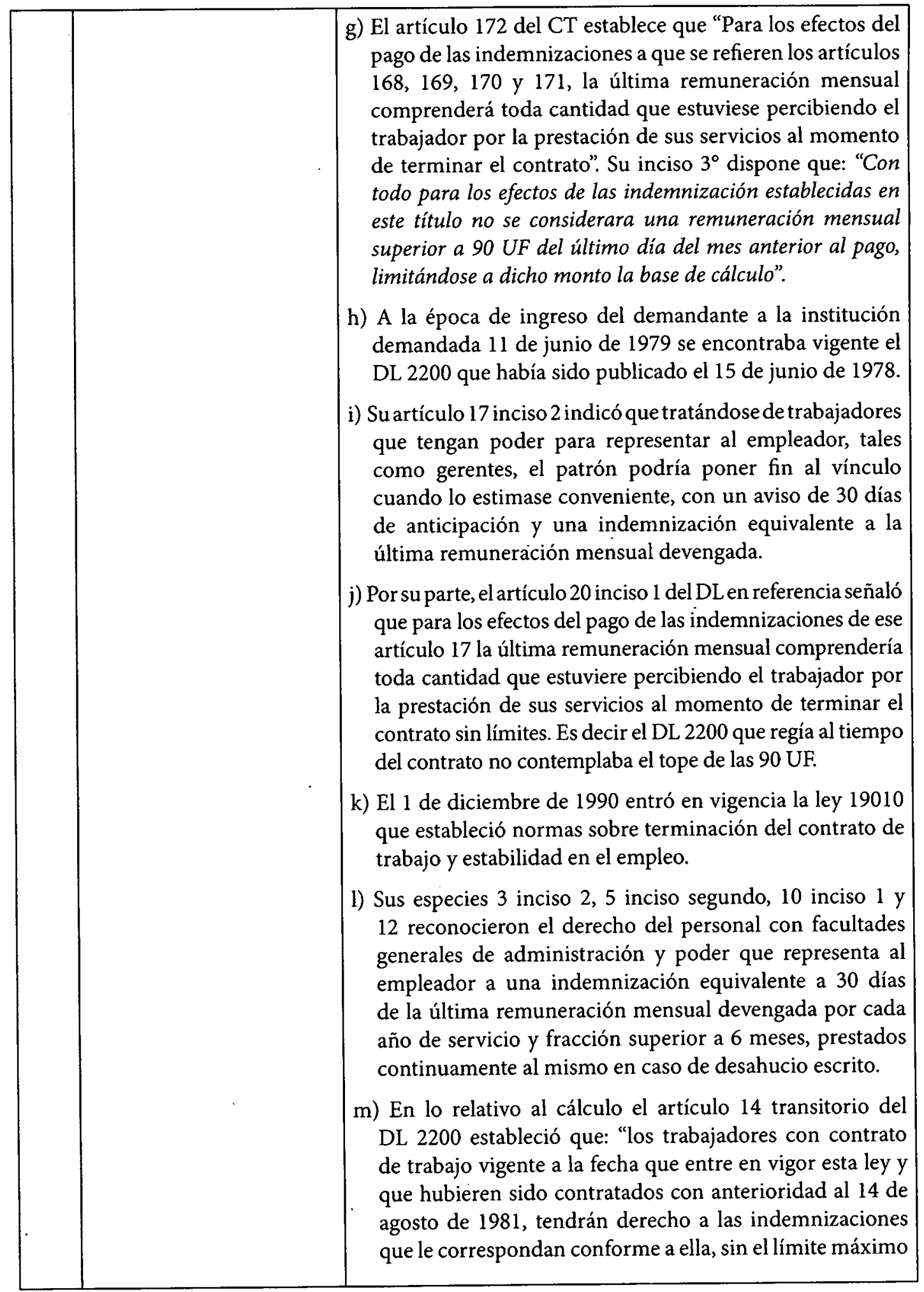




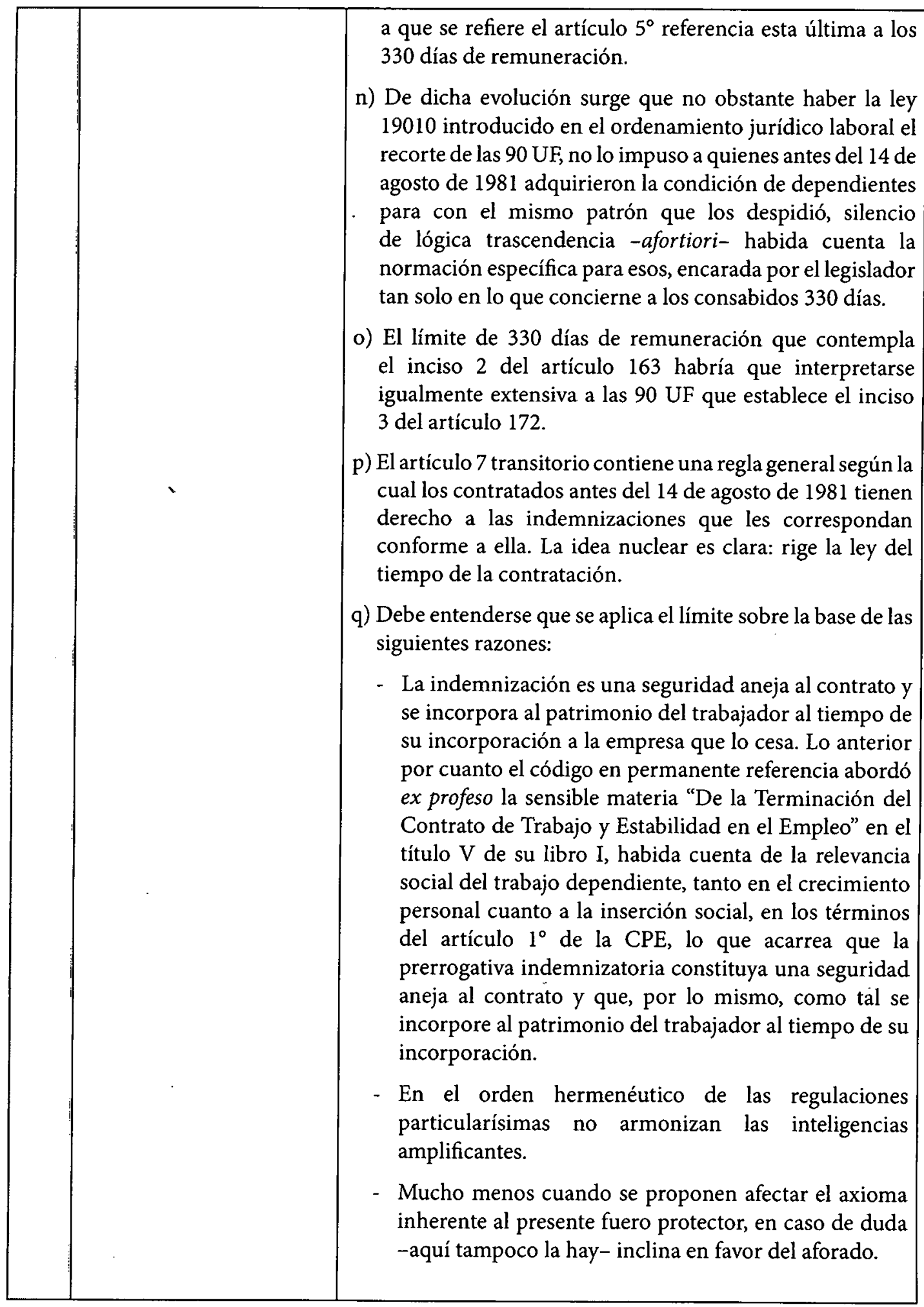


Hugo Fábrega Vega, Cristián Olavarría Rodríguez / Cuadro de unificaciones de jurisprudencia dictadas por la Excma. Corte Suprema (julio de 2014 a julio de 2015)

\begin{tabular}{|c|c|c|}
\hline 12 & $\begin{array}{l}\text { Recurso } N^{\circ} 4003-2014 \text {, } \\
\text { sentencia de } 30 \text { de } \\
\text { septiembre de } 2014 .\end{array}$ & $\begin{array}{l}\text { Jornada superior a } 30 \text { horas } e \text { inferior a } 45 \text { horas semanales. } \\
\text { Improcedencia de ingreso minimo mensual proporcional } \\
\text { Se reiteran argumentos de fallos anteriores. }\end{array}$ \\
\hline 13 & $\begin{array}{l}\text { Recurso } N^{\circ} 4005-2014 \text {, } \\
\text { sentencia de } 30 \text { de } \\
\text { septiembre de } 2014 .\end{array}$ & $\begin{array}{l}\text { Jornada superior a } 30 \text { horas e inferior a } 45 \text { horas semanales. } \\
\text { Improcedencia de ingreso minimo mensual proporcional } \\
\text { Se reiteranargumentos de fallos anteriores. }\end{array}$ \\
\hline 14 & $\begin{array}{l}\text { Recurso } N^{\circ} 3549-2014, \\
\text { sentencia de } 2 \text { de octubre } \\
\text { de } 2014 .\end{array}$ & $\begin{array}{l}\text { Jornada superior a } 30 \text { horas e inferior a } 45 \text { horas semanales. } \\
\text { Improcedencia de ingreso minimo mensual proporcional } \\
\text { Se reitera los criterios anteriores. }\end{array}$ \\
\hline 15 & $\begin{array}{l}\text { Recurso } N^{\circ} 2746-2014 \text {, } \\
\text { sentencia de } 7 \text { de octubre } \\
\text { de } 2014 \text { (rechaza recurso). }\end{array}$ & $\begin{array}{l}\text { Procedimiento de indemnización por daño moral por causa } \\
\text { de un despido indebido que es indemnizado de acuerdo a los } \\
\text { artículos } 162 \text { y } 163 \text { del CT } \\
\text { a) Existen } 2 \text { planos a considerar, por una parte, la } \\
\text { responsabilidad del contratante en cuanto tal en la mira } \\
\text { de la causa y objeto del acuerdo vinculatorio y por la } \\
\text { otra, una responsabilidad del contratante en cuanto ser } \\
\text { humano prescindente de determinado acto jurídico en el } \\
\text { que pueda incidir. } \\
\text { b) Hay consenso en orden a que entre } 2 \text { contratantes sea } \\
\text { factible una responsabilidad contractual a la par de otra } \\
\text { extracontractual en la medida que ésta congenia con una } \\
\text { culpa y un dolo normalmente extraños al sano ejercicio } \\
\text { de las prerrogativas consentidas. } \\
\text { c) En ese caso se enmarca la cesación de un contrato de } \\
\text { trabajo por advenimiento de una o más causales de ley, } \\
\text { así como el juego de las compensaciones sucedáneas, en } \\
\text { su caso. Empece la responsabilidad contractual. Exorbita } \\
\text { esa práctica y se interna en el mundo de la responsabilidad } \\
\text { extracontractual, el comportamiento consistente en ventear } \\
\text { acusaciones falsas a base de hechos que desmedran o } \\
\text { deshonran al otro, cuya condición de trabajador no } \\
\text { lo despoja del derecho a impetrar las compensaciones } \\
\text { concernientes. } \\
\text { d) Las indemnizaciones que la ley establece como } \\
\text { consecuencia del término irregular de un contrato de } \\
\text { trabajo, son de carácter universal, sin que corresponda } \\
\text { demandárseles la satisfacción de esa veta íntima del } \\
\text { patrimonio espiritual, como lo son la honrayla integridad, } \\
\text { donde se anidan inéditas expresiones de privación y } \\
\text { dolor, incompatibles con cualquier previsión de antemano } \\
\text { reguladora. La generalidad de una normativa jamás podrá } \\
\text { abarcar a cabalidad semejante hondura. }\end{array}$ \\
\hline
\end{tabular}




\begin{tabular}{|c|c|c|}
\hline & & $\begin{array}{l}\text { e) El CT establece en el orden de las obligaciones y derechos } \\
\text { un borde a respetar en el sentido que ejercicio de las } \\
\text { facultades que la ley ofrenda al empleador "tiene como } \\
\text { límite el respeto de las garantías constitucionales de los } \\
\text { trabajadores, en especial cuando pudieren afectar la } \\
\text { intimidad, la vida privada o la honra de éstos". } \\
\text { f) Una acusación de falta de honradez es directamente } \\
\text { sugestiva de ausencia de rectitud, probidad, moralidad, } \\
\text { honestidad, integridad. Otra de falta de responsabilidad } \\
\text { trae de suyo a colación la idea de ineptitud, abandono, } \\
\text { indisponibilidad, falta de compromiso, dejación, } \\
\text { indiferencia, desidia, desgano, indolencia. Consumadas } \\
\text { sobre la base de hechos falsos, normalmente han de } \\
\text { generar en el dependiente secuelas que desorbitan el área } \\
\text { propiamente cubierta por el derecho del trabajo, cuyo } \\
\text { apogeo se encuentra recogido en el artículo } 2 \text { del CT, en } \\
\text { el sentido de la dignidad de la persona ha de presidir las } \\
\text { relaciones afines. } \\
\text { g) Entre las guías hermenéuticas se comprende axioma pro } \\
\text { homine del Derecho del Trabajo. } \\
\text { h) De este modo, en una perspectiva holistica del asunto, } \\
\text { tampoco se divisaría razón para, en la encrucijada, cerrar } \\
\text { la puerta del procedimiento de general aplicación por causa } \\
\text { de despido indebido, improcedente o injustificado al anhelo } \\
\text { reivindicatorio del mal moral. }\end{array}$ \\
\hline 16 & $\begin{array}{l}\text { Recurso } N^{\circ} \quad 638-2014 \text {, } \\
\text { sentencia de } 14 \text { de octubre } \\
\text { de } 2014 \text {. }\end{array}$ & $\begin{array}{l}\text { Finiquito. Reserva (articulo } 177 \text { del CT) } \\
\text { a) El punto gira en torno al grado de eficacia que conduce lo } \\
\text { que una de las partes dice "guardarse" en el mismo acto } \\
\text { jurídico que certifica el total acuerdo de voluntades en } \\
\text { cuanto a considerar absoluta y definitivamente sellado el } \\
\text { vínculo que las unió. } \\
\text { b) No se controvierte que los litigantes suscribieron un } \\
\text { finiquito en la modalidad del artículo } 177 \text { del estatuto. } \\
\text { c) El demandante declaró: (i) recibir a su entera satisfacción } \\
\text { una suma determinada "como la única que le corresponde } \\
\text { percibir ala terminación desus servicios, ... sea porconcepto } \\
\text { de... indemnizaciones legales..." (cláusula segunda); (ii) } \\
\text { declaró que se le pagaba "en forma integra, oportuna y } \\
\text { a su entera satisfacción..." toda clase de "prestación legal } \\
\text { o convencional derivada, directa o indirectamente... de la } \\
\text { terminación..." del contrato, al punto que a la cantidad } \\
\text { que recibe en la ocasión "se imputará cualquier pago o }\end{array}$ \\
\hline
\end{tabular}




\begin{tabular}{|c|c|c|}
\hline & & $\begin{array}{l}\text { indemnización a que pudiere tener derecho, sea legal o } \\
\text { contractualmente, dándose pagado totalmente con ella de } \\
\text { todas las prestaciones derivadas del Contrato de Trabajo, } \\
\text { de su terminación..., entendiendo... que el presente } \\
\text { documento constituye una transacción para todos los } \\
\text { efectos legales." (cláusula tercera);(iii) que otorga "el más } \\
\text { amplio, completo, total y definitivo finiquito, renunciando } \\
\text { expresamente en este acto a cualquier acción judicial... en } \\
\text { lo relacionado al término del" contrato (cláusula cuarta); } \\
\text { (iv) que se obliga a no deducir acción judicial en el futuro } \\
\text { en relación con tales materias (cláusula quinta). } \\
\text { d) Por aplicación de las reglas generales, para que una } \\
\text { persona se obligue a otra por un acto o declaración de } \\
\text { voluntad es en todo caso menester que ésta recaiga sobre } \\
\text { un objeto, que, a su vez, ha de ser determinado. } \\
\text { e) Cuando el acuerdo de voluntades ha sido tan rigurosamente } \\
\text { estructurado como el que se investigó en la argumentación } \\
\text { que antecede, no puede dejar dudas cuanto a su exacto y } \\
\text { verdadero alcance, por manera que al entendimiento de } \\
\text { toda persona con sano ejercicio de la razón significa que y } \\
\text { sólo que el querer de los suscribientes-declarantes no es } \\
\text { otro que el dedesligarse por siempre, asumiendo con plena } \\
\text { conciencia que nada subsiste pendiente. Las palabras han } \\
\text { sido de tal modo holisticas que no han dejado espacios. } \\
\text { Para cualquier persona normal no es concebible manera } \\
\text { otra de finitud. Es el omega. } \\
\text { f) No se divisa el objeto de un apéndice del finiquito que } \\
\text { dice: "Me Reservo el Derecho a Reclamo Posterior'.. La } \\
\text { indeterminación no es casual. Es consubstancial. Nada } \\
\text { se dejó abierto. Imposible definir la finalidad y destino del } \\
\text { hipotético reclamo ulterior. } \\
\text { g) Ha de reivindicarse para el finiquito laboral de que } \\
\text { trata el artículo } 177 \text { del Código del Trabajo el requisito } \\
\text { indispensable de recaer sobre cosa determinada o, si de } \\
\text { cantidad se trata, razonablemente determinable, tal como } \\
\text { lo sostienen las sentencias cuya doctrina la demandada } \\
\text { blande en su favor. }\end{array}$ \\
\hline 17 & $\begin{array}{l}\text { Recurso } \mathrm{N}^{\circ} 3515-2014, \\
\text { sentencia de } 21 \text { de octubre } \\
\text { de } 2014 \text {. }\end{array}$ & $\begin{array}{l}\text { Tutela de derechos fundamentales en Ministerio Público } \\
\text { Se reitera lo ya resuelto en fallos anteriores. }\end{array}$ \\
\hline
\end{tabular}




\begin{tabular}{|c|c|c|}
\hline 18 & $\begin{array}{l}\text { Recurso } N^{\circ} \text { 1058-2014, } \\
\text { sentencia de } 28 \text { de octubre } \\
\text { de } 2014 \text { (cambio de } \\
\text { criterio). }\end{array}$ & $\begin{array}{l}\text { Ley } N^{\circ} 20.281 \text {. Diferencias por concepto de } 6 \text { meses de sueldo } \\
\text { base en relación al ingreso minimo } \\
\text { a) Se había sostenido que realizado por el empleador con } \\
\text { cargo a los emolumentos variables del trabajador por el } \\
\text { plazo de } 6 \text { meses no tenía fecha de término en tanto se } \\
\text { tratare del ajuste necesario para llegar al valor del ingreso } \\
\text { mínimo de la época que era de } \$ 159.000 \text {.- } \\
\text { b) La sentencia modificó criterio sosteniendo que existen } 2 \\
\text { interpretaciones: (i) la primera sostiene que la norma tuvo } \\
\text { por objeto otorgar un plazo de } 6 \text { meses a los empleadores } \\
\text { para realizar los ajustes necesarios para equiparar el } \\
\text { sueldo base pactado con el ingreso mínimo mensual, } \\
\text { en el evento que aquel sea inferior a éste, cargando las } \\
\text { diferencias a la parte variable de las remuneraciones de } \\
\text { los trabajadores. Realizado dicho ajuste, el empleador } \\
\text { cumple con la obligación de remunerar al dependiente } \\
\text { con un sueldo base, a lo menos, igual al mínimo legal } \\
\text { y (ii) la segunda argumenta que ese plazo de } 6 \text { meses } \\
\text { se concedió para que el empleador hiciera el ajuste } \\
\text { necesario imputando las diferencias a la parte variable } \\
\text { de la remuneración y transcurrido dicho plazo, ya no le } \\
\text { estaba permitido realizar la imputación en los términos } \\
\text { señalados. } \\
\text { c) El objetivo de la ley fue corregir la anomalía en orden a la } \\
\text { existencia de pactos laborales que contemplan sueldos base, } \\
\text { incluso de valor insignificante, siendo el objetivo de la ley la } \\
\text { asimilación del sueldo base al ingreso mínimo legal. } \\
\text { d) Considerando dicho objetivo no puede interpretarse que } \\
\text { disposición del empleador, luego si el objetivo fue asimilar } \\
\text { el sueldo base al ingreso mínimo legal imponiendo a } \\
\text { los empleadores la obligación de mantener los pactos } \\
\text { en marcha el nuevo sistema remuneracional permitiendo } \\
\text { descontar de la parte variable de los estipendios la } \\
\text { diferencia necesaria para alcanzar el valor del ingreso } \\
\text { mínimo legal, sino que la interpretación coherente } \\
\text { con el fin del legislador es entender que se facultó al } \\
\text { empleador para que dentro de ese lapso cargara el ajuste } \\
\text { a las remuneraciones, pero no con posterioridad al } \\
\text { vencimiento del referido plazo. }\end{array}$ \\
\hline
\end{tabular}




\begin{tabular}{|c|c|c|}
\hline & & $\begin{array}{l}\text { que sí lo establezcan y facultándolos para realizar el ajuste } \\
\text { necesario unilateralmente, no se divisa razón por la cual } \\
\text { la ley transcurrido el plazo de } 6 \text { meses, permitiera que sea } \\
\text { el propio dependiente el que se mantenga en situación de } \\
\text { pagarse su ingreso mínimo legal en el estipendio variable } \\
\text { que genera mensualmente con su mayor productividad. } \\
\text { f) Es decir no resulta lógico que la ley asegure un mínimo } \\
\text { por el solo hecho de cumplir jornada laboral y que el } \\
\text { empleador lo impute a la parte de la remuneración. }\end{array}$ \\
\hline 19 & $\begin{array}{l}\text { Recurso } N^{\circ} 4699- \\
2014 \text {, sentencia de } 6 \text { de } \\
\text { noviembre de } 2014 .\end{array}$ & $\begin{array}{l}\text { Contrato por obra o faena. Concesión. Indefinido (articulo } \\
159 N^{\circ} 6 \text { ) } \\
\text { a) El contrato por obra o faena se caracteriza porque su } \\
\text { objeto es la ejecución de una obra material o servicio } \\
\text { determinado que por su naturaleza propia o intrínseca } \\
\text { tiene el carácter de transitorio o temporal. Esto es, son } \\
\text { obras o servicios en que es posible reconocer un principio } \\
\text { y un fin, el que viene dado por la conclusión, debidamente } \\
\text { explicitada en el contrato, de la obra que se ejecuta o del } \\
\text { servicio que se presta. } \\
\text { b) El recurrente sostiene, por el contrario que, la temporalidad } \\
\text { del contrato viene dada no por el tipo de servicio prestado } \\
\text { por el trabajador, sino que por el contrato que el empleador } \\
\text { celebró con la Municipalidad a quien provee servicios de } \\
\text { aseo, lo que constituye una comprensión errónea de la } \\
\text { figura en cuestión. } \\
\text { c) Elhecho que el empleadorhaya sido contratado para proveer } \\
\text { servicios a un tercero por un periodo determinado, no } \\
\text { convierte, por ese solo hecho el contrato de trabajo de quienes } \\
\text { contrata para desempeñar esa función en uno por obra o } \\
\text { faena. Si asi fuera se estaría transformando, en definitiva, } \\
\text { en un contrato dependiente, o sujeto a la existencia de un } \\
\text { contrato principal, categoría que, claramente; no tiene } \\
\text { cabida dentro de nuestro ordenamiento juridico laboral y } \\
\text { pugna, fundamentalmente, con el principio de estabilidad } \\
\text { en el empleo consagrado en nuestro ordenamiento. } \\
\text { d) Nuestro ordenamiento jurídico en cuanto al tiempo } \\
\text { reconoce } 2 \text { tipos de contrato: (i) los primeros de carácter } \\
\text { excepcional y asi fluye de la regulación restrictiva que se } \\
\text { contiene en el artículo } 159 \text { No } 4 \text { del CT respecto de los } \\
\text { contratos a plazo que consecuente con ello, privilegia } \\
\text { el imperio de la regla general en la materia, que no es } \\
\text { otra que la naturaleza indefinida de los contratos. Por lo }\end{array}$ \\
\hline
\end{tabular}




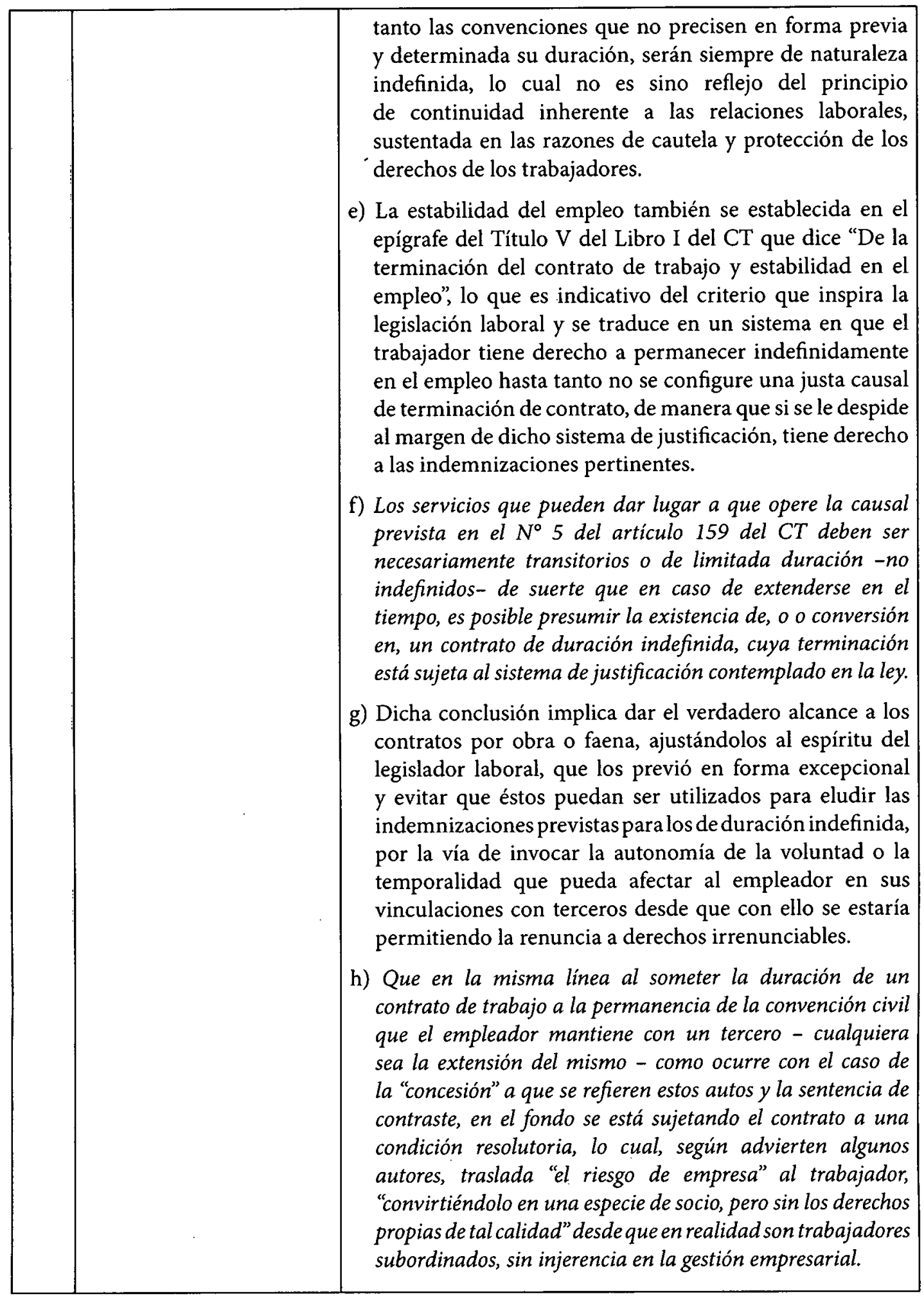




\begin{tabular}{|c|c|c|}
\hline 20 & $\begin{array}{l}\text { Recurso } N^{\circ} 3825-2014, \\
\text { sentencia de } 11 \text { de } \\
\text { noviembre de } 2014 .\end{array}$ & $\begin{array}{l}\text { Jornada superior a } 30 \text { horas e inferior a } 45 \text { horas semanales. } \\
\text { Improcedencia de ingreso mínimo mensual proporcional } \\
\text { a) Se reitera los criterios anteriores en el sentido que una } \\
\text { jornada de } 36 \text { horas semanales para todos los efectos } \\
\text { legales, tiene la naturaleza de jornada ordinaria. } \\
\text { b) Dicha naturaleza se desprende de la normativa del hecho } \\
\text { que a partir de la vigencia de la Ley } 19.759 \text {, que estableció } \\
\text { la jornada parcial, la única jornada parcial admitida } \\
\text { por el legislador es aquella cuyo máximo es de } 30 \text { horas } \\
\text { semanales y no otra. En ese mismo sentido cuando el } \\
\text { artículo } 44 \text { inciso } 3 \text { del CT autoriza a pagar un sueldo } \\
\text { proporcional, dicha excepción está referida únicamente } \\
\text { a la situación allí descrita, es decir, a los contratos con } \\
\text { jornada parcial, entendida esta como la definida en el } \\
\text { artículo } 40 \text { bis del CT. } \\
\text { c) El hecho que el artículo } 40 \text { bis A inciso } 2^{\circ} \text { del CT } \\
\text { introducido por la Ley } 19.988 \text { de diciembre de } 2004 \text {, o } \\
\text { conforme lo dispone el artículo } 32 \text {, inciso } 3^{\circ} \text { del CT. } \\
\text { Lo anterior descarta la existencia de jornadas parciales } \\
\text { superiores a } 30 \text { horas semanales pues el exceso se } \\
\text { entienden como horas extraordinarias. }\end{array}$ \\
\hline 21 & $\begin{array}{l}\text { Recurso } \mathrm{N}^{\circ} 4301-2014, \\
\text { sentencia de } 11 \text { de } \\
\text { noviembre de } 2014 .\end{array}$ & $\begin{array}{l}\text { Agravio requisito esencial en recurso de nulidad y de } \\
\text { unificación de jurisprudencia. Despido indirecto y tutela de } \\
\text { derechos fundamentales (artículo } 489 \text { inciso } 3^{\circ} \text { del CT) } \\
\text { a) En el caso era un despido indirecto en que se condena a } \\
\text { pagar indemnización por años de servicio, sustitutiva de } \\
\text { aviso previo, adicional del artículo } 489 \text { inciso } 3^{\circ} \text { del CT. } \\
\text { b) Se alegó incompatibilidad de la tutela con el despido } \\
\text { indirecto. No obstante ello, la sentencia de la Corte de } \\
\text { Apelaciones de San Miguel indicó: "Que, si bien es cierto } \\
\text { que el tribunal habría infringido el artículo } 489 \text { inciso } \\
\text { tercero del Código del Trabajo, al concederla indemnización } \\
\text { adicional en un caso en que no correspondia, y retomando } \\
\text { lo dicho en el considerando tercero de esta sentencia, } \\
\text { dicho error no tiene influencia en lo dispositivo del fallo, } \\
\text { lo que conlleva el rechazo de esta primera causal, ya que } \\
\text { la sentenciadora, al tener por acreditado el daño padecido } \\
\text { por el trabajador, según se consignó expresamente en } \\
\text { la sentencia, de todas formas debia de conceder una } \\
\text { indemnización al trabajador por los perjuicios causados, } \\
\text { cuyo monto hubiese sido exactamente el mismo al otorgado } \\
\text { por la otra via, puesto que la sentenciadora, junto con dar }\end{array}$ \\
\hline
\end{tabular}




\begin{tabular}{|c|c|c|}
\hline & . & $\begin{array}{l}\text { por acreditado el perjuicio sufrido, declaró expresamente en } \\
\text { elconsiderando } 21^{\circ} \text {, que "respecto aldaño moral demandado, } \\
\text { atendido lo ya referido y que con la indemnización adicional } \\
\text { se resarce el perjuicio causado, y que los hechos señalados } \\
\text { por el denunciante como fundamento del daño moral son los } \\
\text { mismos considerados para la alegación de la vulneración de } \\
\text { garantía constitucional y que la prueba aportada también } \\
\text { es la misma, habiéndose producido ya el resarcimiento } \\
\text { de tal vulneración mediante la indemnización adicional } \\
\text { en su máximum, sin que se hayan expresado ni probado } \\
\text { otras circunstancias que podrian justificar tal pretensión, } \\
\text { se rechazará la misma". } \\
\text { c) Corresponde exigir como requisito de procedencia tanto } \\
\text { del recurso de unificación de jurisprudencia como del } \\
\text { recurso de nulidad el agravio sustancial correspondiente, } \\
\text { es decir, la resolución contraria a los intereses o peticiones } \\
\text { de quien recurre. } \\
\text { d) Se desestima el recurso de nulidad de la demandada en } \\
\text { relación con la incompatibilidad de las acciones ejercidas } \\
\text { por el actor, sobre la base de sostener que el vicio advertido } \\
\text { carece de influencia sustancial en lo dispositivo del fallo, es } \\
\text { decir, aun cuando se entendiera cometido nada distinto } \\
\text { pudo decidirse, porque la indemnización pertinente habría } \\
\text { de concederse o por la vía del inciso tercero del articulo } \\
489 \text { del Código del Trabajo o a título de indemnización } \\
\text { por daño moral, esto es, igualmente la demandada habría } \\
\text { recibido la condena resarcitoria contra la que reclama. }\end{array}$ \\
\hline 22 & $\begin{array}{l}\text { Recurso } \mathrm{N}^{\circ} 4061-2014 \text {, } \\
\text { sentencia de } 18 \text { de } \\
\text { noviembre de } 2014 .\end{array}$ & $\begin{array}{l}\text { Contrato por obra o faena (artículo } 159 \mathrm{~N}^{\circ} 5 \mathrm{del} C T \text { ) } \\
\text { Se reitera lo resuelto en fallos anteriores. }\end{array}$ \\
\hline 23 & $\begin{array}{l}\text { Recurso } N^{\circ} 2547-2014 \text {, } \\
\text { sentencia de } 24 \text { de } \\
\text { noviembre de } 2014 .\end{array}$ & $\begin{array}{l}\text { Accidente del Trabajo y culpa levisima del empleador (artículo } \\
184 \text { del CT en relación a artículo } 1547 \text { del CC) } \\
\text { a) Considera los siguientes normas: (i) artículo } 184 \text { del CT; } \\
\text { (ii) artículo } 68 \text { de la Ley } N^{\circ} 16.744 \text {; (iii) artículo } 1547 \text { del } \\
\text { CT y (iv) artículo } 21 \text { del DS } 40 \text { de } 1969 \text { (obligación de } \\
\text { informar los riesgos a los trabajadores). } \\
\text { b) Del artículo } 184 \text { del CT se desprende, como ha fallado en } \\
\text { otras ocasiones la CS, que el empleador se constituye en } \\
\text { deudor de seguridad de sus trabajadores, lo cual importa } \\
\text { exigirla adopción de todas las medidas correctas y eficientes } \\
\text { destinadas a proteger la vida y salud de aquellos. }\end{array}$ \\
\hline
\end{tabular}


Hugo Fábrega Vega, Cristián Olavarría Rodríguez / Cuadro de unificaciones de jurisprudencia dictadas por la Excma. Corte Suprema (julio de 2014 a julio de 2015)

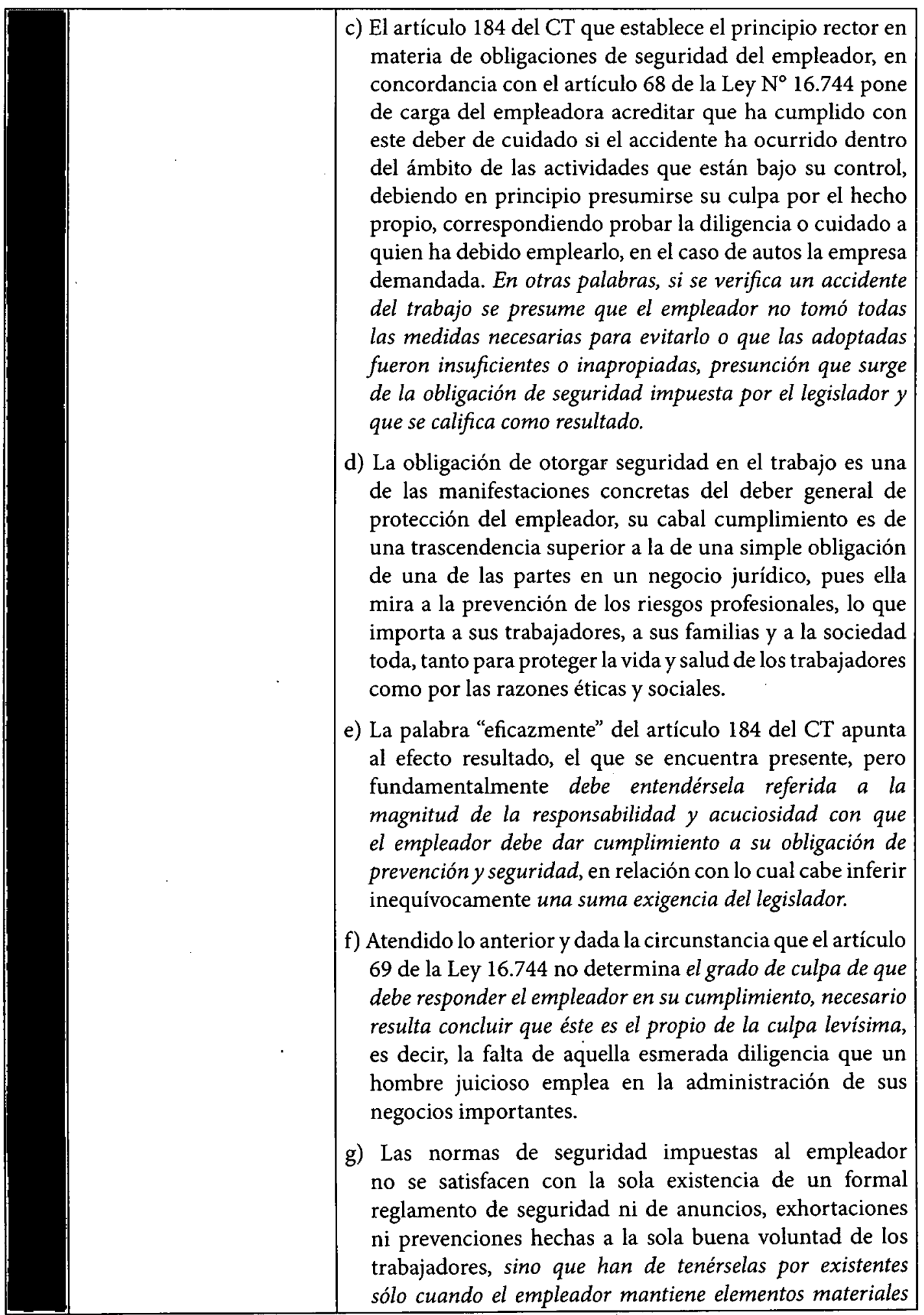


Hugo Fábrega Vega, Cristián Olavarría Rodríguez / Cuadro de unificaciones de jurisprudencia dictadas por La Excma. Corte Suprema

\begin{tabular}{|c|c|c|}
\hline & . & $\begin{array}{l}\text { constantes y supervigilancia auténtica en cuanto a la forma } \\
\text { como deba o haya de desarrollarse la actividad de los } \\
\text { trabajadores, especialmente en faenas peligrosas. } \\
\text { h) Los jueces de la instancia, en vez de exigir a la demandada } \\
\text { prueba idónea del cumplimiento de su obligación de } \\
\text { asegurar eficazmente la vida de uno de sus trabajadores, } \\
\text { traspasaron dicho peso procesal a la demandante en } \\
\text { orden a que ésta demostrara que existieron presiones de } \\
\text { la parte patronal para que incumpliera lo pactado en el } \\
\text { contrato de trabajo y las prohibiciones reguladas en el } \\
\text { Reglamento de Higiene y Seguridad sobre los descansos } \\
\text { previstos para la segunda noche de trayecto-entre las } 3,00 \\
\text { y las } 6,00 \text { horas- arguyendo directamente a la carga de } \\
\text { la prueba que, por sus alegaciones, le imponía el artículo } \\
\text { 1698 del CC. } \\
\text { i) Los encargados de supervisar la operación de transporte } \\
\text {-contando con elementos modernos para seguir el } \\
\text { tiempo de real desplazamiento- no ejecutaron las } \\
\text { medidas preventivas ante las infracciones al contrato en } \\
\text { que incurría el chofer del camión, no rindiendo prueba } \\
\text { la demandada que realizó actividades idóneas o eficaces } \\
\text { para prevenir la ocurrencia del accidente. }\end{array}$ \\
\hline 24 & $\begin{array}{l}\text { Recurso } N^{\circ} 3668-2014 \text {, } \\
\text { sentencia de } 27 \text { de } \\
\text { noviembre de } 2014 .\end{array}$ & $\begin{array}{l}\text { Retraso en el pago de remuneraciones y cotizaciones } \\
\text { previsionales } \\
\text { a) La cotización previsional es un gravamen que pesa sobre } \\
\text { las remuneraciones de los trabajadores. } \\
\text { b) La omisión del empleador de enterar dicha cotización } \\
\text { ante la institución previsional respectiva constituye un } \\
\text { incumplimiento de la obligación que impone el contrato } \\
\text { de trabajo consistente en el pago íntegro y oportuno de la } \\
\text { remuneración del trabajador. } \\
\text { c) El incumplimiento reviste la gravedad suficiente cuando } \\
\text { el empleador es contumaz en su conducta. } \\
\text { d) El hecho de declarar las cotizaciones y no pagarlas } \\
\text { oportunamente no deja de configurar un incumplimiento } \\
\text { de las obligaciones que impone el contrato. Representa } \\
\text { una forma de facilitar su cobro a cambio de disminuir } \\
\text { la carga accesoria de carácter pecuniaria que tal atraso } \\
\text { conlleva. Sin embargo en ese caso la remuneración no ha } \\
\text { sido pagada íntegramente. }\end{array}$ \\
\hline
\end{tabular}


Hugo Fábrega Vega, Cristián Olavarría Rodríguez / Cuadro de unificaciones de jurisprudencia dictadas por la Excma. Corte Suprema (julio de 2014 a julio de 2015)

\begin{tabular}{|c|c|c|}
\hline & & $\begin{array}{l}\text { e) El retraso en las remuneraciones constituye un } \\
\text { incumplimiento de las obligaciones que impone el } \\
\text { contrato. Aceptar el atraso implica traspasar al trabajador } \\
\text { el riesgo de la empresa que es propio del empleador. } \\
\text { f) El no pago reiterado de las cotizaciones previsionales y el } \\
\text { retardo en el pago de las remuneraciones constituye un } \\
\text { incumplimiento grave de las obligaciones que impone el } \\
\text { contrato de trabajo. }\end{array}$ \\
\hline 25 & $\begin{array}{l}\text { Recurso } \mathrm{N}^{\circ} \text { 3514-2014, } \\
\text { sentencia de } 4 \text { de diciembre } \\
\text { de } 2014 \text { (rechaza recurso). } \\
\text { (Votos en contra de } \\
\text { abogados Peralta y Prado) }\end{array}$ & $\begin{array}{l}\text { Reemplazo de Trabajadores en huelga (art. } 381 \text { CT). } \\
\text { Entre otras razones: } \\
\text { - Se tiene que la visión vertida en autos por la empresa } \\
\text { no se conforma con los fines ni con los valores que } \\
\text { inspiran los superiores derechos de sindicalización y } \\
\text { de negociación colectiva. } \\
\text { - Sin repetir lo que ya se ha predicado sobre el particular, } \\
\text { ocurre que las prerrogativas que recogen las especies } \\
\text { 16a inciso antepenúltimo y 19a de la Constitución } \\
\text { Política de la República no son indiferentes entre sí, lo } \\
\text { que se traduce en que, de cara al derecho a declarar la } \\
\text { huelga -ínsito en los dos últimos párrafos de la primera } \\
\text { de las mencionadas- sus respectivas autonomías se } \\
\text { conjuguen en un todo, por manera que el derecho } \\
\text { a la declaración de la huelga legal es una suerte de } \\
\text { coronación esencial del de libertad sindical, a través } \\
\text { del normado ejercicio del de negociación colectiva. } \\
\text { - Todos son fines y causas a la vez. Cada uno de } \\
\text { ellos ha de ser visto como causa final de los otros. } \\
\text { En esa conjunción se anida lo más esencial de las } \\
\text { potencialidades del trabajo organizado, desde la } \\
\text { perspectiva del factor débil de la relación laboral. } \\
\text { - A la luz de su fin y valor, resulta insostenible la tesis de la } \\
\text { parte patronal, quepretende escindir el derecho delibertad } \\
\text { sindical del de declaración de huelga y su concretización. }\end{array}$ \\
\hline 26 & $\begin{array}{l}\text { Recurso } \mathrm{N}^{\circ} 6939- \\
2014 \text {, sentencia de } 11 \\
\text { de diciembre de } 2014 \\
\text { (rechaza recurso). }\end{array}$ & $\begin{array}{l}\text { Agravio. Requisito esencial del recurso de unificación de } \\
\text { jurisprudencia }\end{array}$ \\
\hline 27 & $\begin{array}{l}\text { Recurso } \mathrm{N}^{\circ} 5698- \\
2014 \text {, sentencia de } 11 \\
\text { de diciembre de } 2014 \\
\text { (rechaza recurso). }\end{array}$ & $\begin{array}{l}\text { Agravio. Requisito esencial del recurso de unificación de } \\
\text { jurisprudencia } \\
\text { Defecto de la sentencia que no influye en lo dispositivo del } \\
\text { fallo no permite dar lugar a la unificación de jurisprudencia. }\end{array}$ \\
\hline
\end{tabular}




\begin{tabular}{|c|c|c|}
\hline 28 & $\begin{array}{l}\text { Recurso } \mathrm{N}^{\circ} 4299- \\
2014 \text {, sentencia de } 18 \\
\text { de diciembre de } 2014 \\
\text { (cambio de criterio). }\end{array}$ & $\begin{array}{l}\text { Despido indirecto y sanción de nulidad de despido (art. } 162 \\
\text { CT). Procedencia } \\
\text { a) El trabajador terminó la relación laboral por } \\
\text { incumplimiento grave de las obligaciones emanadas del } \\
\text { contrato de trabajo. } \\
\text { b) El despido indirecto es una modalidad de despido y en } \\
\text { ningún caso una renuncia. } \\
\text { c) Luego, sus efectos deben ser los mismos que emanan } \\
\text { cuando la relación laboral se finiquita por voluntad del } \\
\text { empleador. } \\
\text { d) Que si no se interpretara de otra forma bastaría que el } \\
\text { empleador incurriere en causales de caducidad, incluidas } \\
\text { las del pago de cotizaciones y mantener un estado de } \\
\text { ilicitud en el evento que el trabajador no haga uso del } \\
\text { despido indirecto. }\end{array}$ \\
\hline 29 & $\begin{array}{l}\text { Recurso } N^{\circ} 4656-2014 \text {, } \\
\text { sentencia de } 29 \text { de } \\
\text { diciembre de } 2014 . \\
\text { (Voto en contradeabogado } \\
\text { integrante Barahona por } \\
\text { defecto formal) }\end{array}$ & $\begin{array}{l}\text { Causal de término de art. } 159 \mathrm{~N}^{\circ} 5 \mathrm{CT} \text { y contrato indefinido. } \\
\text { a) El contrato por obra o faena es un contrato de carácter } \\
\text { temporal. } \\
\text { b) Hay } 2 \text { clases de contratos, los de duración determinada } \\
\text { a plazo o por obra o faena y los de duración indefinida. } \\
\text { c) La regla general son los contratos indefinidos. } \\
\text { d) La causal del art. } 159 \mathrm{~N}^{\circ} 5 \mathrm{CT} \text { solo opera en contratos de } \\
\text { duración determinada y temporales. } \\
\text { e) Un contrato de obra o faena puede transformarse en } \\
\text { indefinido por el hecho de seguir prestando servicios el } \\
\text { trabajador después de concluida la obra o faena. }\end{array}$ \\
\hline 30 & $\begin{array}{l}\text { Recurso } N^{\circ} 5000 \text { - 2014, } \\
\text { sentencia de } 8 \text { de enero de } \\
2014 \text {. } \\
\text { (Voto en contra de } \\
\text { abogados integrantes } \\
\text { Peralta y Prado por forma } \\
\text { no hay presupuestos } \\
\text { fácticos claros) }\end{array}$ & $\begin{array}{l}\text { Finiquito y Reserva (art. } 177 \mathrm{CT} \text { ) } \\
\text { a) El poder liberatorio del finiquito se restringe a todo } \\
\text { aquello en que las partes han concordado expresamente } \\
\text { y no se extiende a los aspectos en que el consentimiento } \\
\text { no se formó, sea porque una de las partes formula la } \\
\text { reserva correspondiente, sea porque se trate de derechos } \\
\text { u obligaciones no especificados por los comparecientes, } \\
\text { sea por cualquiera otras razones que el entendimiento } \\
\text { humano pudiera abarcar. } \\
\text { b) La reserva dice: "el derecho a reclamar por la causal de } \\
\text { despido invocada, y por el cálculo de remuneraciones, } \\
\text { indemnizaciones yotros conceptos laborales que hayalugar, } \\
\text { sin perjuicio de otras acciones que procedieren". }\end{array}$ \\
\hline
\end{tabular}


Hugo Fábrega Vega, Cristián Olavarría Rodríguez / Cuadro de unificaciones de jurisprudencia dictadas por la Excma. Corte Suprema (julio de 2014 a julio de 2015)

\begin{tabular}{|c|c|c|}
\hline & & $\begin{array}{l}\text { c) Concluye que la reserva se refiere a lo reclamado en la } \\
\text { demanda que fue el incremento del } 30 \% \text { del art. } 168 \mathrm{CT} \text {. } \\
\text { d) En este caso no es vago la reclamación del despido } \\
\text { injustificado. }\end{array}$ \\
\hline 31 & $\begin{array}{l}\text { Recurso } N^{\circ} 8891-2014 \text {, } \\
\text { sentencia de } 15 \text { de enero } \\
\text { de } 2014 .\end{array}$ & $\begin{array}{l}\text { Desafuero maternal. Expresión "podrá" } \\
\text { - La prerrogativa concedida al juez en el art.174 CT supone } \\
\text { la adecuado y fundada ponderación de los elementos de } \\
\text { convicción incorporados al proceso por los litigantes para } \\
\text { los efectos de conceder o no la autorización para despedir } \\
\text { a una trabajadora amparada por fuero materno, sea que } \\
\text { se trate de las causales subjetivas o de las objetivas a las } \\
\text { que dicha disposición se refiere, únicas para las que se } \\
\text { otorga al empleador la acción de desafuero previa a la } \\
\text { desvinculación. } \\
\text { - Se reitera criterio anterior. }\end{array}$ \\
\hline 32 & $\begin{array}{l}\text { Recurso } N^{\circ} 10.466-2014 \text {, } \\
\text { sentencia de } 27 \text { de enero } \\
\text { de } 2014 .\end{array}$ & $\begin{array}{l}\text { Jornada de trabajo parcial es la inferior a } 30 \text { horas semanales } \\
\text { Reitera criterio anterior. }\end{array}$ \\
\hline 33 & $\begin{array}{l}\text { Recurso } N^{\circ} 10.444-2014 \text {, } \\
\text { sentencia de } 29 \text { de enero } \\
\text { de } 2015 \text {. } \\
\text { (Voto en contra de } \\
\text { abogado integrante Prado) }\end{array}$ & $\begin{array}{l}\text { Prohibición de reemplazo interno en la huelga } \\
\text { Reitera criterio modificado. }\end{array}$ \\
\hline 34 & $\begin{array}{l}\text { Recurso } N^{\circ} 11.639-2015 \text {, } \\
\text { sentencia de } 3 \text { de marzo } \\
\text { de } 2014 \text {. }\end{array}$ & $\begin{array}{l}\text { Aspecto formal. Si la sentencia objeto del recurso de } \\
\text { unificación de jurisprudencia fue rechazada solo por forma } \\
\text { resulta improcedente el recurso de unificación. }\end{array}$ \\
\hline 35 & $\begin{array}{l}\text { Recurso } N^{\circ} 8318-2014, \\
\text { sentencia de } 3 \text { de marzo de } \\
2015 \text { (cambio de criterio). } \\
\text { (Voto en contra de } \\
\text { abogado integrante Prado) }\end{array}$ & $\begin{array}{l}\text { Relación laboral determinada en la sentencia. Procedencia de } \\
\text { la sanción de nulidad de despido (art. } 162 \mathrm{CT} \text { ) } \\
\text { a) Sobre la base de una situación jurídica dada en el caso } \\
\text { de autos una relación laboral, se dedujo demanda además } \\
\text { para que se declarara injustificado el despido, que este } \\
\text { fue nulo e ineficaz porque las cotizaciones no estaban } \\
\text { pagadas. } \\
\text { b) Se constató su existencia pero en ningún caso se } \\
\text { constituyó. } \\
\text { c) No registra su nacimiento desde que quedó ejecutoriada } \\
\text { la sentencia sino que en la oportunidad en que las partes } \\
\text { se constituyeron. Cosa distinta es que una de las partes se } \\
\text { resista a dar cumplimiento. }\end{array}$ \\
\hline
\end{tabular}




\begin{tabular}{|c|c|c|}
\hline 36 & $\begin{array}{l}\text { Recurso } N^{\circ} 11.831-2015 \\
\text { sentencia de } 5 \text { de marzo } \\
\text { de } 2015 .\end{array}$ & $\begin{array}{l}\text { Aspecto formal. Si la sentencia objeto del recurso de unificación } \\
\text { de jurisprudencia fue rechazada "solo por forma" resulta } \\
\text { improcedente el recurso de unificación }\end{array}$ \\
\hline 37 & $\begin{array}{l}\text { Recurso } N^{\circ} 11448-2014, \\
\text { sentencia de } 2 \text { de marzo } \\
\text { de } 2015 .\end{array}$ & $\begin{array}{l}\text { Rechaza recurso de unificación por forma pero consta } \\
\text { sentencia que autoriza indemnización por daño moral en caso } \\
\text { de tutela (una excepción) }\end{array}$ \\
\hline 38 & $\begin{array}{l}\text { Recurso } \mathrm{N}^{\circ} 10.674-2014, \\
\text { sentencia de } 5 \text { de marzo } \\
\text { de } 2015 \text {. }\end{array}$ & $\begin{array}{l}\text { Aspecto formal. Si la sentencia objeto del recurso de unificación } \\
\text { de jurisprudencia fue rechazada "solo por forma" resulta } \\
\text { improcedente el recurso de unificación }\end{array}$ \\
\hline 39 & $\begin{array}{l}\text { Recurso } N^{\circ} 10.636-2014, \\
\text { sentencia de } 11 \text { de marzo } \\
\text { de } 2015 .\end{array}$ & $\begin{array}{l}\text { La carta de despido queda indisolublemente unida a los hechos } \\
\text { que deben acreditarse en el juicio } \\
\text { a) En la carta de despido se debe indicar el motivo del mismo. } \\
\text { b) La desvinculación debe apoyarse en hechos específicos y } \\
\text { no genéricos. } \\
\text { c) Lo expresado en la carta de despido queda indisolublemente } \\
\text { unido a los hechos que deben acreditarse en el juicio. } \\
\text { d) Los hechos en que se funda no pueden ser modificados } \\
\text { por el empleador durante el juicio. }\end{array}$ \\
\hline 40 & $\begin{array}{l}\text { Recurso } N^{\circ} 7784-2014, \\
\text { sentencia de } 12 \text { de marzo } \\
\text { de } 2015 \text {. }\end{array}$ & $\begin{array}{l}\text { Jornada de trabajo parcial sólo es aquella inferior a } 30 \text { horas } \\
\text { Reitera criterio anterior. }\end{array}$ \\
\hline 41 & $\begin{array}{l}\text { Recurso } \mathrm{N}^{\circ} 11.718-2014, \\
\text { sentencia de } 12 \text { de marzo } \\
\text { de } 2015 .\end{array}$ & $\begin{array}{l}\text { Inclusión de asignaciones de colación y movilización en base } \\
\text { de cálculo de indemnización por años de servicio } \\
\text { Ratifica criterio de permanencia para incluir conceptos en } \\
\text { la base de cálculo de las indemnizaciones por término de } \\
\text { contrato de trabajo. }\end{array}$ \\
\hline 42 & $\begin{array}{l}\text { Recurso } N^{\circ} 21.641 \text { - } 2014, \\
\text { sentencia de } 25 \text { de marzo } \\
\text { de } 2015\end{array}$ & $\begin{array}{l}\text { Inclusión de asignaciones de colación y movilización en base } \\
\text { de cálculo de indemnización por años de servicio } \\
\text { Ratifica criterio de permanencia anterior. }\end{array}$ \\
\hline 43 & $\begin{array}{l}\text { Recurso } \mathrm{N}^{\circ} 11.582-2014, \\
\text { sentencia de } 26 \text { de marzo } \\
\text { de } 2015\end{array}$ & $\begin{array}{l}\text { Jornada parcial es aquella que no excede de } 30 \text { horas semanales } \\
\text { Ratifica criterio consistente que es jornada completa el que } \\
\text { excede de } 30 \text { horas semanales. }\end{array}$ \\
\hline 44 & $\begin{array}{l}\text { Recurso } \mathrm{N}^{\circ} 11584-2014 \\
\text { sentencia de } 1^{\circ} \text { de abril de } \\
2015 .\end{array}$ & $\begin{array}{l}\text { Estatuto Administrativo. Contrato a honorarios } \\
\text { a) El art } 1 \text { del CT dispone que: "Las relaciones laborales entre } \\
\text { empleadores y trabajadores se regularán por este Código y } \\
\text { por sus leyes complementarios". } \\
\text { "Estas normas no se aplicarán, sin embargo, a los } \\
\text { funcionarios de la Administración del Estado, centralizada, } \\
\text { descentralizada, del Congreso Nacional y del Poder Judicial, }\end{array}$ \\
\hline
\end{tabular}




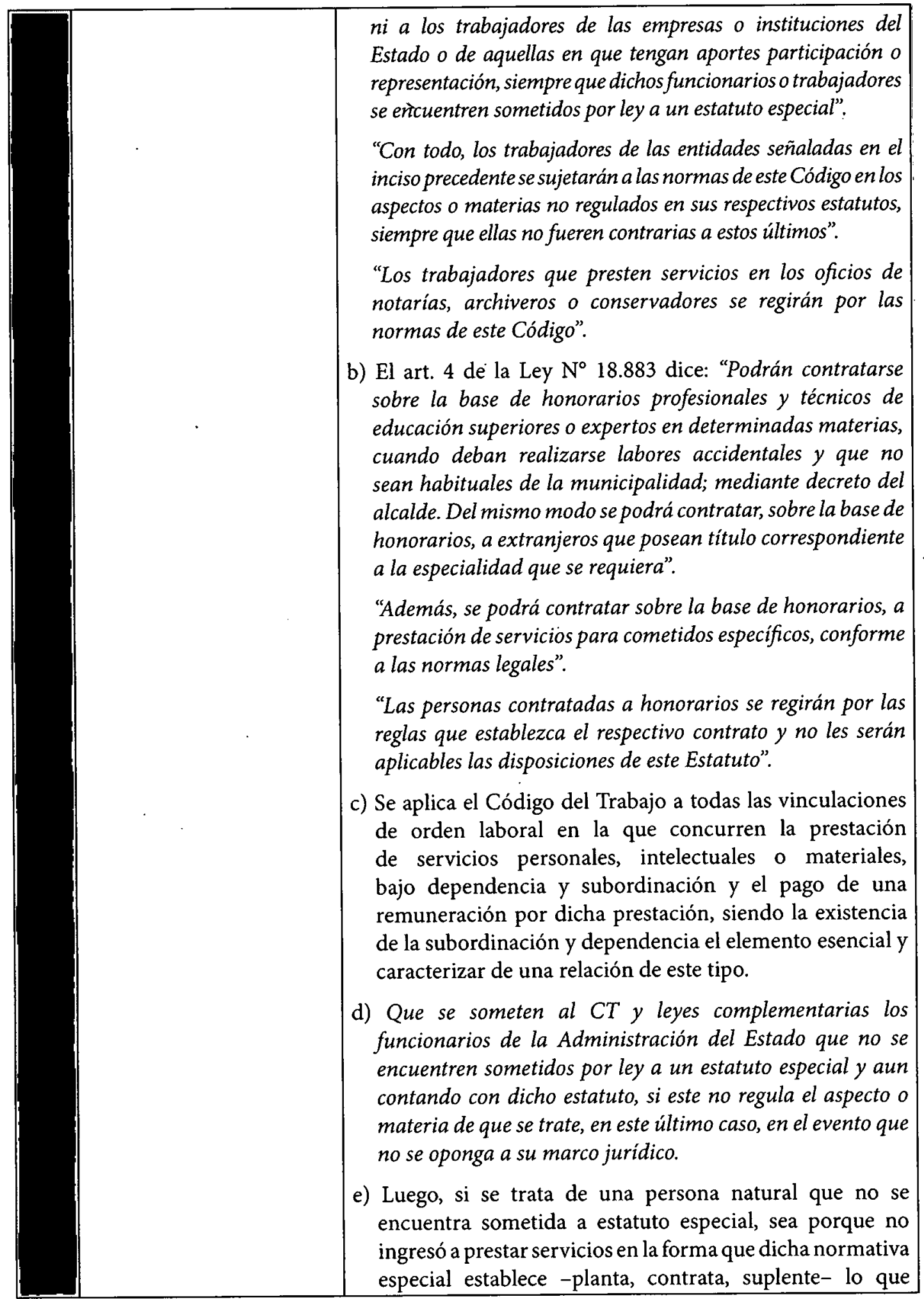




\begin{tabular}{|c|c|c|}
\hline & . & $\begin{array}{l}\text { en la especie acontece inconcluso resulta que la disyuntiva } \\
\text { se orienta hacia la aplicación del CT o CC, conclusión que } \\
\text { deriva que en el caso se invoca el art. } 4 \text { de la Ley 18.883, } \\
\text { norma que permite contratar sobre la base de honorarios en } \\
\text { las condiciones que indica, las que en general, se asimilan al } \\
\text { arrendamiento de servicios personales regulados en el CC } \\
\text { y que, ausentes, excluyen de su ámbito las vinculaciones } \\
\text { pertinentes, correspondiendo subsumirlas en la normativa } \\
\text { del CT, en el evento que se presenten rasgos características } \\
\text { de este tipo de relaciones. } \\
\text { Lo anterior no solo porque la vigencia del CT es la regla } \\
\text { general en el campo de las relaciones personales, sino } \\
\text { porque no es dable admitirla informalidad laboraly suponer } \\
\text { que por tratarse de un órgano del Estado, que debe someterse } \\
\text { al principio de juridicidad, recogido en los artículos } 6 \text { y } 7 \text { de } \\
\text { la CPE, puede invocar esa legalidad para propiciar dicha } \\
\text { precariedad e informalidad laboral, la que por lo demás se } \\
\text { encuentra proscrita por el Estado de Derecho. } \\
\text { f) Se uniforma jurisprudencia, en el sentido que corresponde } \\
\text { calificar como vinculaciones laborales, sometidas al CT, } \\
\text { a las relaciones habidas entre una persona natural y un } \\
\text { órgano de la Administración del Estado, en la especie, una } \\
\text { Municipalidad, en la medida que dichas vinculaciones } \\
\text { se desarrollen fuera del marco legal que establece - para } \\
\text { el caso - el articulo } 4 \text { de la Ley No } 18.883 \text {, que autoriza } \\
\text { la contratación sobre la base de honorarios ajustada a las } \\
\text { condiciones que dicha norma describe, en la medida que las } \\
\text { relaciones se conformen a las exigencias establecidas por el } \\
\text { legislador laboral para los efectos de entenderlas reguladas } \\
\text { por la codificación correspondiente. }\end{array}$ \\
\hline 45 & $\begin{array}{l}\text { Recurso } N^{\circ} 11.671-2014 \text {, } \\
\text { sentencia de } 7 \text { de abril de } \\
2015 \text {. }\end{array}$ & $\begin{array}{l}\text { Procedencia de sanción de nulidad de despido (art. } 162 \mathrm{CT} \text { ) } \\
\text { en caso de término de contrato a plazo fijo por vencimiento del } \\
\text { plazo (art. } 159 \mathrm{~N}^{\circ} 5 \mathrm{CT} \text { ) } \\
\text { a) La hipótesis de término de contrato de trabajo por } \\
\text { vencimiento del plazo queda comprendida dentro de } \\
\text { aquellas en que resulta procedente la aplicación de la } \\
\text { nulidad de despido contenida en el inciso } 5^{\circ} \text { del art. } 162 \mathrm{CT} \text {. } \\
\text { b) La expresión "despido" es comprensiva de todas las formas } \\
\text { de terminación de la relación laboral que señalan los incisos } \\
\text { precedentes, entre los cuales esta los contratos a plazo. } \\
\text { c) El objetivo de la norma fue fomentar el pago de las } \\
\text { cotizaciones previsionales en forma íntegra y oportuna, }\end{array}$ \\
\hline
\end{tabular}


Hugo Fábrega Vega, Cristián Olavarría Rodríguez / Cuadro de unificaciones de jurisprudencia dictadas por la Excma. Corte Suprema (julio de 2014 a julio de 2015)

\begin{tabular}{|c|c|c|}
\hline & . & $\begin{array}{l}\text { por lo que no se ve razón para excluir dicha cuestión a } \\
\text { determinadas formas de terminación del contrato de } \\
\text { trabajo, como es el vencimiento del plazo convenido. }\end{array}$ \\
\hline 46 & $\begin{array}{l}\text { Recurso } N^{\circ} 12.906-2014, \\
\text { sentencia de } 7 \text { de abril de } \\
2015 . \\
\text { (Voto en contra de } \\
\text { abogado } \\
\text { Peralta) }\end{array}$ & $\begin{array}{l}\text { Improcedencia de aplicar el contrato colectivo a trabajadores } \\
\text { de la empresa que modifica contratos individuales de } \\
\text { dependientes miembros del Sindicato sin que implique una } \\
\text { vulneración al art. } 5 \text { inciso } 2 \text { del CT } \\
\text { a) El conflicto se limita a determinar el alcance de la Cláusula } \\
2^{\circ} \text { letra B } \mathrm{N}^{\circ} 1 \text { del contrato colectivo de } 16.06 .11 \text { sobre si } \\
\text { era procedente fijar un suelo base equivalente al ingreso } \\
\text { mínimo mensual a aquellos trabajadores que a la fecha de } \\
\text { su entrada en vigencia tenían un sueldo base superior al } \\
\text { referido ingreso mínimo. } \\
\text { b) Se refiere la sentencia al artículo } 5 \text { inc. } 2 \text { del CT, al art.11 } \\
\text { inc. } 1 \text { y al art. } 1545 \text { CC y } 1563 \text { CC. } \\
\text { c) El Derecho del Trabajo contiene normas indisponibles, } \\
\text { lo que significa que el trabajador no puede renunciar } \\
\text { válidamente a los derechos de la norma ya que forman } \\
\text { parte de su contrato ingresando a su patrimonio. } \\
\text { d) Los contratos de trabajo individuales y colectivos deben } \\
\text { estar subordinados a la ley y no puede contener clausulas } \\
\text { inferiores a las de la ley. } \\
\text { e) La autonomía de las partes deben respetar los límites } \\
\text { legales y convencionales. } \\
\text { f) Que los artículos } 303 \text { y } 306 \text { CC previenen que el objeto } \\
\text { del proceso de negociación colectiva es establecer } \\
\text { condiciones comunes de trabajo y de remuneraciones por } \\
\text { un tiempo determinado u otros beneficios. } \\
\text { g) Luego el objeto de la negociación colectiva cuya finalidad } \\
\text { se alcanza con el contrato colectivo, es obtener mayores } \\
\text { y mejores condiciones de trabajo de la empresa y elevar } \\
\text { el nivel de vida de los trabajadores y no desmejorar su } \\
\text { situación remuneracional. } \\
\text { que lo permita el art. } 5 \text { inc. } 2 \text { del CT. En este caso ello no } \\
\text { ocurre ya que las partes en anexo de contrato individual } \\
\text { acordaron un sueldo base superior al ingreso mínimo } \\
\text { mensual, lo que no puede ser alterado con posterioridad } \\
\text { mediante la aplicación de un contrato colectivo imponiendo } \\
\text { una situación desmejorada a los impugnantes. }\end{array}$ \\
\hline
\end{tabular}




\begin{tabular}{|c|c|c|}
\hline 47 & $\begin{array}{l}\text { Recurso } \mathrm{N}^{\circ} 13.334-2014, \\
\text { sentencia de } 7 \text { de abril de } \\
2015 \text { (rechaza recurso). } \\
\text { (Voto en contra ministros } \\
\text { Blanco y Muñoz que } \\
\text { establece criterio muy } \\
\text { restrictivo de caso fortuito } \\
\text { o fuerza mayor) }\end{array}$ & $\begin{array}{l}\text { Causal de término de contrato de caso fortuito o fuerza } \\
\text { mayor ( artículo } 159 \mathrm{~N}^{\circ} 6 \mathrm{CT} \text { ) } \\
\text { - Se rechaza porque no hay interpretaciones disímiles, } \\
\text { concluyéndose que la existencia de una segunda planta en } \\
\text { una ciudad distinta no implica la posibilidad de mantener } \\
\text { vigentes los contratos de trabajo. }\end{array}$ \\
\hline 48 & $\begin{array}{l}\text { Recurso } N^{\circ} \quad 11.671 \\
\text { sentencia de } 7 \text { de abril de } \\
2015 .\end{array}$ & $\begin{array}{l}\text { Compatibilidad entre art. } 159 N^{\circ} 4 \text { y nulidad del despido (art. } \\
\text { 162) }\end{array}$ \\
\hline 49 & $\begin{array}{l}\text { Recurso } N^{\circ} 11.586-2014, \\
\text { sentencia de } 8 \text { de abril de } \\
2015 .\end{array}$ & $\begin{array}{l}\text { Semana corrida (art. } 45 \mathrm{CT} \text { ) (rechazado por forma) } \\
\text { - Se mantienen criterios de los fallos anteriores en materia } \\
\text { de semana corrida en relación que procede respecto de } \\
\text { remuneraciones variables diarias. }\end{array}$ \\
\hline 50 & $\begin{array}{l}\text { Recurso } N^{\circ} 19.354-2014, \\
\text { sentencia de } 9 \text { de abril de } \\
2015 .\end{array}$ & $\begin{array}{l}\text { Desafuero maternal. Expresión "podrá" } \\
\text { - La prerrogativa concedida al juez en el art.174 CT supone } \\
\text { la adecuado y fundada ponderación de los elementos de } \\
\text { convicción incorporados al proceso por los litigantes para } \\
\text { los efectos de conceder o no la autorización para despedir } \\
\text { a una trabajadora amparada por fuero materno, sea que } \\
\text { se trate de las causales subjetivas o de las objetivas a las } \\
\text { que dicha disposición se refiere, únicas para las que s } \\
\text { otorga al empleador la acción de desafuero previa a la } \\
\text { desvinculación. }\end{array}$ \\
\hline 51 & $\begin{array}{l}\text { Recurso } N^{\circ} \quad 21.933, \\
\text { sentencia de } 14 \text { de abril de } \\
2015 .\end{array}$ & $\begin{array}{l}\text { Base de cálculo de indemnizaciones por término de contrato de } \\
\text { trabajo excluye conceptos "ocasionales" y no los permanentes } \\
\text { - Deben descartarse de la noción de última remuneración } \\
\text { mensual para los efectos a que se refiere, aquellos } \\
\text { beneficios o asignaciones que tienen el carácter de } \\
\text { ocasionales, esto es, esporádicos o que se solucionan una } \\
\text { vez al año. }\end{array}$ \\
\hline 52 & $\begin{array}{l}\text { Recurso } N^{\circ} 22.339-2014, \\
\text { sentencia de } 14 \text { de abril de } \\
2015 .\end{array}$ & $\begin{array}{l}\text { Revisión de sana crítica a través de unificación de } \\
\text { jurisprudencia } \\
\text { - Con el objeto de no trastocar el sistema recursivo el examen } \\
\text { que debe efectuar el tribunal superior no puede llevar } \\
\text { a que, en la práctica, se convierta en uno de instancia, } \\
\text { valorando directamente la prueba rendida en el juicio, y } \\
\text { es por ello que solo le corresponde revisar si en el proceso } \\
\text { racional llevado a cabo por el tribunal de base se respetó } \\
\text { la lógica, las máximas de experiencia y los conocimientos }\end{array}$ \\
\hline
\end{tabular}


Hugo Fábrega Vega, Cristián Olavarría Rodríguez / Cuadro de unificaciones de jurisprudencia dictadas por la Excma. Corte Suprema (julio de 2014 a julio de 2015)

\begin{tabular}{|c|c|c|}
\hline & & $\begin{array}{l}\text { científicamente afianzados; labor que se traduce en analizar } \\
\text { de manera pormenorizada las argumentaciones que } \\
\text { condujeron al juzgado del grado a dar por acreditados los } \\
\text { hechos que debian ser probados y, sobre dicha base, decidir } \\
\text { el asunto litigioso en uno u otro sentido; postulado que, } \\
\text { en consecuencia, constituye la correcta interpretación } \\
\text { sobre la materia de derecho que se trajo a esta sede, y, por } \\
\text { lo tanto, corresponde acoger el recurso que se analiza y } \\
\text { unificar la jurisprudencia en el sentido indicado, y anular } \\
\text { la sentencia impugnada para acto continuo, en forma } \\
\text { separada, dictar la correspondiente de reemplazo. }\end{array}$ \\
\hline 53 & $\begin{array}{l}\text { Recurso } N^{\circ} 19.374-2014, \\
\text { sentencia de } 23 \text { de abril de } \\
2015 \text { (cambio de criterio } \\
\text { respecto de finiquito). }\end{array}$ & $\begin{array}{l}\text { Calificación del contrato de obra y faena y poder libertario del } \\
\text { finiquito (Arts. } 159 N^{\circ} 5 \text { y } 177 \text { del CT) } \\
\text { a) El contrato por obra o faena se produce cuando aparece } \\
\text { en forma explícita en el contrato y el trabajador haya } \\
\text { tomado conocimiento de la temporalidad de los servicios } \\
\text { a prestar. Se caracteriza porque su objeto es la ejecución } \\
\text { de una obra material o un servicio determinado que, } \\
\text { por su naturaleza propia o intrínseca, tiene el carácter } \\
\text { de transitorio o temporal, esto es, son obras o servicios } \\
\text { en que es posible reconocer un principio o un fin, el que } \\
\text { viene dado por la conclusión, debidamente explicitada en } \\
\text { el contrato, de la obra que se ejecuta o del servicio que se } \\
\text { presta. } \\
\text { b) En la interpretación el recurrente se pretende que la } \\
\text { temporalidad del contrato viene dada no por el tipo } \\
\text { de servicio prestado por el trabajador, sino por el } \\
\text { contrato de concesión "asesoría de Inspección Técnica } \\
\text { a la Explotación de Obras Concesionadas: Programa } \\
\text { de Concesiones de Infraestructura Penitenciaria- } \\
\text { Grupo Uno". Es una interpretación errónea. En efecto, } \\
\text { el hecho que el empleador haya sido contratado para } \\
\text { proveer dichos servicios a un tercero, por un periodo } \\
\text { determinado no convierte por ese solo hecho, el contrato } \\
\text { de trabajo de quien contrata para desempenar esa } \\
\text { función en uno por obra o faena. Si asi fuera- si pudiera } \\
\text { sostenerse que el contrato del trabajador subsiste mientras } \\
\text { este vigente el contrato del empleador con aquel tercero, } \\
\text { con independencia de la naturaleza de la obra o servicio } \\
\text { que se prestase estaría transformando, en definitiva, en un } \\
\text { contrato dependiente, no tiene cabida dentro de nuestro } \\
\text { ordenamiento juridico laboral ypugna, fundamentalmente, } \\
\text { con el principio de estabilidad en el empleo consagrado en } \\
\text { nuestro ordenamiento. }\end{array}$ \\
\hline
\end{tabular}




\begin{tabular}{|c|c|c|}
\hline & & $\begin{array}{l}\text { c) En el ordenamiento nacional hay un sistema en que el } \\
\text { trabajador tiene derecho a permanecer indefinidamente } \\
\text { en el empleo hasta que no se configure una justa causal de } \\
\text { terminación de contrato. } \\
\text { d) Los servicios que pueden dar lugar a que opere la causal } \\
\text { del } \mathrm{N}^{\circ} 5 \mathrm{del} \text { art. } 159 \mathrm{CT} \text { deben ser necesariamente } \\
\text { transitorias o limitada duración- no indefinidos -de } \\
\text { suerte que en caso de extenderse en el tiempo, es posible } \\
\text { presumir la existencia de, o conversión en, un contrato } \\
\text { de duración indefinida cuya terminación esta sujeta } \\
\text { al sistema de justificación contemplado en la ley. No } \\
\text { basta solo con plasmar en el contrato la calificación del } \\
\text { contrato como uno por obra o faena, como ocurre en la } \\
\text { especie sino que dicha calificación debe ser coherente con } \\
\text { las condiciones y relación laboral ejecutada por las partes } \\
\text { (segunda renovación). } \\
\text { e) Finiquito. Al asumir la relación laboral como o indefinida, } \\
\text { lo finiquitos posteriores deben estimarse ineficaces, los que } \\
\text { carecen de poder liberatorio al fundarse en una causal de } \\
\text { termino impertinente, lo que redunda en afectar derechos } \\
\text { irrenunciables para la trabajadora, la que mantenia } \\
\text { una relación contractual vigente con la demandante al } \\
\text { momento en que fueron celebrados. }\end{array}$ \\
\hline 54 & $\begin{array}{l}\text { Recurso } N^{\circ} 22.136-2014 \text {, } \\
\text { sentencia de } 23 \text { de abril de } \\
2015 .\end{array}$ & $\begin{array}{l}\text { Rechazado por forma. Diferentes presupuestos fácticos (art. } \\
160 N^{\circ} 3 \text { y detención de trabajador). Interesante voto disidente } \\
\text { de R. Blanco. }\end{array}$ \\
\hline 55 & $\begin{array}{l}\text { Recurso } \mathrm{N}^{\circ} 2.829-2014, \\
\text { sentencia de } 5 \text { de mayo de } \\
2015 .\end{array}$ & $\begin{array}{l}\text { Acoge recurso de unificación en materia de prescripción } \\
\text { extintiva, no siendo aplicable art. } 510 \text { del CT sino arts. } 2.214 \text { y } \\
2.215 \text { del Código Civil por aplicación de ley } 15.840 \text { : } \\
\text { - Si bien de acuerdo a lo dispuesto en el artículo } 68 \text { de } \\
\text { dicho cuerpo legal, quienes fueron contratados como } \\
\text { obreros por la Dirección General de Obras Públicas y } \\
\text { sus servicios dependientes, se encontraban regidos por el } \\
\text { Código del Trabajo, mientras mantuvieran esa condición } \\
\text { laboral, circunstancia que podría conducir a entender } \\
\text { aplicables también las normas de prescripción en el caso } \\
\text { planteado, lo cierto es que, como se ha observado, los } \\
\text { beneficios establecidos en el artículo } 80 \text { de la ley } 15.840 \\
\text { y, en particular, la indemnización por años de servicio, } \\
\text { tienen su origen en dicha ley especial y no en las normas } \\
\text { del Código del Trabajo, de suerte que no resulta aplicable } \\
\text { en la especie lo dispuesto en el artículo } 510 \text { del Código }\end{array}$ \\
\hline
\end{tabular}




\begin{tabular}{|c|c|c|}
\hline & & $\begin{array}{l}\text { del Trabajo, desde que dicho precepto alcanza o regula, } \\
\text { únicamente, "los derechos regidos por este Código". } \\
\text { - El tenor de dicha disposición es restrictivo, no se refiere } \\
\text { a los derechos de carácter laboral en general, sino sólo } \\
\text { a aquéllos que dicho cuerpo normativo regula, lo } \\
\text { que impide extender el plazo de prescripción por él } \\
\text { contemplado, a otros derechos o beneficios, no obstante } \\
\text { su naturaleza o carácter laboral, si éstos tienen su origen } \\
\text { en una ley diversa al Código del ramo. } \\
\text { - La hipótesis en estudio tampoco corresponde a lo previsto } \\
\text { en el inciso segundo de la norma en estudio, por cuanto } \\
\text { este regula la prescripción de "las acciones provenientes } \\
\text { de los actos y contratos a que se refiere este Código" -para } \\
\text { lo cual establece un plazo de seis meses contados desde } \\
\text { la terminación de los servicios- no siendo el beneficio } \\
\text { indemnizatorio de marras, uno de origen convencional, } \\
\text { sino legal. } \\
\text { Al no existir en la ley } 15.840 \text { un plazo de prescripción } \\
\text { especial para el beneficio laboral antes descrito, en opinión } \\
\text { de este tribunal, deben aplicarse las reglas del derecho } \\
\text { común, lo que nos remite a lo dispuesto en el artículo } 2515 \\
\text { del Código Civil, el que en relación al artículo } 2514 \text { del } \\
\text { mismo cuerpo legal, establece un plazo de prescripción } \\
\text { para las acciones ordinarias de cinco años contado desde } \\
\text { que la obligación se hubiere hecho exigible. } \\
\text { En consecuencia, la sentencia impugnada ha incurrido en } \\
\text { el yerro que se denuncia, al estimar que procede aplicar en } \\
\text { la especie el plazo de prescripción de dos años previsto en } \\
\text { el artículo } 510 \text { del Código del Trabajo, a la indemnización } \\
\text { por años de servicios que el demandante reclama, con } \\
\text { base en lo dispuesto en el artículo } 80 \text { de la ley } 15.840 .\end{array}$ \\
\hline 56 & $\begin{array}{l}\text { Recurso } \mathrm{N}^{\circ} 15.293-2014, \\
\text { sentencia de } 12 \text { de Mayo } \\
\text { de } 2015 .\end{array}$ & $\begin{array}{l}\text { Prohibición de reemplazo interno en la huelga. } \\
\text { Reitera criterio modificado. }\end{array}$ \\
\hline 57 & $\begin{array}{l}\text { Recurso } N^{\circ} 23.638-2014, \\
\text { sentencia de } 18 \text { de Mayo } \\
\text { de } 2015 .\end{array}$ & $\begin{array}{l}\text { Compatibilidad entre autodespido y nulidad del despido. } \\
\text { Reitera criterio modificado mediante cita a ingreso } 15.323 \text { - } \\
2013 \text { destacando en lo medular: } \\
\text { - En síntesis, sostuvo que el despido indirecto constituye } \\
\text { un reproche a la conducta del empleador que incurre en } \\
\text { una causal de caducidad del contrato y que los efectos } \\
\text { del ejercicio de la facultad otorgada al dependiente en } \\
\text { el artículo } 171 \text { del Código del Trabajo, no pueden sino }\end{array}$ \\
\hline
\end{tabular}




\begin{tabular}{|c|c|c|}
\hline & $\cdot$ & $\begin{array}{l}\text { ser los mismos que derivan del despido ejercido por el } \\
\text { empleador. } \\
\text { - En ese contexto, estableció que la sanción contemplada en } \\
\text { el artículo } 162 \text { del Código del Trabajo debe ser aplicada } \\
\text { cuando es el trabajador quien pone término al contrato, } \\
\text { en la medida que se cumpla cabalmente con la situación } \\
\text { de hecho que la hace surgir, cual es que se adeuden } \\
\text { cotizaciones previsionales al término de la relación } \\
\text { laboral. } \\
\text { - La sentencia argumenta en el sentido que la finalidad de } \\
\text { la llamada Ley Bustos fue la de proteger los derechos } \\
\text { previsionales del trabajador, ante el incumplimiento del } \\
\text { empleador en el integro de sus cotizaciones, la que no } \\
\text { se cumpliría si sólo se considerara aplicable la sanción } \\
\text { al caso del dependiente que es despedido por voluntad } \\
\text { unilateral del empleador. } \\
\text { - De seguirse la interpretación opuesta, concluye esta Corte } \\
\text { al unificar jurisprudencia, se estaría avalando un estado de } \\
\text { ilicitud que contraría el fin perseguido por la Ley 19.631 } \\
\text { y promoviendo un estado de cosas que en último término } \\
\text { favorece y promueve el incumplimiento del empleador. }\end{array}$ \\
\hline 58 & $\begin{array}{l}\text { Recurso } N^{\circ} 19.352-2014, \\
\text { sentencia de } 9 \text { de junio de } \\
2015 . \\
\text { (Prevención interpretativa } \\
\text { abogado integrante } \\
\text { Correa) }\end{array}$ & $\begin{array}{l}\text { Imposibilidad de alegar hechos distintos que aquellos que } \\
\text { figuran en comunicación de despido. } \\
\text { - "En fin, por ello y por mucho más la Corte se siente en el } \\
\text { deber de unificar la jurisprudencia en el señalado sentido, } \\
\text { procurando que en lo sucesivo se respete cabalmente la } \\
\text { ritualidad del momento excepcional en que una de las } \\
\text { partes pone término a un contrato de trabajo, so pena } \\
\text { de recibir como sanción, entre otras, la del artículo } 454 \\
\text { tantas veces comentado, a saber, el no poder defender su } \\
\text { conducta en el procedimiento a que ello diere lugar". }\end{array}$ \\
\hline 59 & $\begin{array}{l}\text { Recurso } N^{\circ} 24.388-2014, \\
\text { sentencia de } 9 \text { de julio de } \\
2015 \text { (cambio de criterio). }\end{array}$ & $\begin{array}{l}\text { Califica como laboral prestación de servicios regida por el } \\
\text { Estatuto Administrativo en situación que indica } \\
\text { - Si una persona se incorpora a la dotación de una } \\
\text { municipalidad bajo la modalidad contemplada. en el } \\
\text { artículo } 4 \text { de la Ley } \mathrm{N}^{\circ} 18.883 \text {, pero, no obstante ello, en } \\
\text { la práctica presta un determinado servicio que no tiene } \\
\text { la característica específica y particular que señala dicha } \\
\text { norma, o que tampoco se desarrolla en las condiciones de } \\
\text { temporalidad que indica, corresponde aplicar el Código } \\
\text { del Trabajo si los servicios se han prestado bajo los } \\
\text { supuestos fácticos ya señalados en el motivo anterior, y }\end{array}$ \\
\hline
\end{tabular}




\begin{tabular}{|c|c|}
\hline 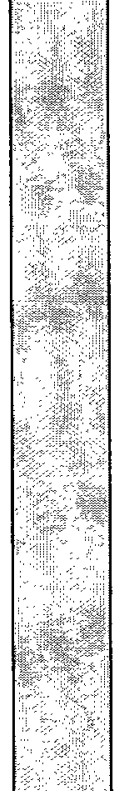 & $\begin{array}{l}\text { que conducen necessariamente a la conclusión que es de } \\
\text { orden laboral. } \\
\text { - Lo anterior, porque dicho código constituye la regla } \\
\text { general en el ámbito de las relaciones laborales, y, además, } \\
\text { porque una conclusión en sentido contrario significaría } \\
\text { admitir que, no obstante concurrir todos los elementos de } \\
\text { un contrato de trabajo, el trabajador queda al margen del } \\
\text { Estatuto Laboral, en una situación de precariedad laboral } \\
\text { que no tiene justificación alguna; } \\
\text { En consecuencia, se uniforma la jurisprudencia en el } \\
\text { sentido que corresponde calificar como laboral y, por } \\
\text { lo tanto, regida por el Código del Trabajo, la relación } \\
\text { que se genera entre una persona y un órgano de la } \\
\text { Administración del Estado si se desarrolla fuera del } \\
\text { contexto claro y preciso que señala el artículo } 4 \text { de la Ley } \\
N^{\circ} 18.883 \text {,y se configuran todos los presupuestos fácticos } \\
\text { que el legislador laboral establece para ese efecto. }\end{array}$ \\
\hline
\end{tabular}

